Mulus Surgana, Anang Setiawan, Megawati, Elok Mulyoutami, Badri Dwi Meldy, Syamsidar, Rahma Talui, Janudianto, S Suyanto dan James M. Roshetko 

Seri Agroforestri dan Kehutanan di Sulawesi:

\section{Kebutuhan penyuluhan agroforestri pada tingkat masyarakat di lokasi proyek AgFor di Sulawesi Selatan dan Tenggara, Indonesia}

Endri Martini, Jusupta Tarigan, Pratiknyo Purnomosidhi, Andi Prahmono, Mulus Surgana, Anang Setiawan, Megawati, Elok Mulyoutami, Badri Dwi Meldy, Syamsidar, Rahma Talui, Janudianto, S Suyanto dan James M. Roshetko 


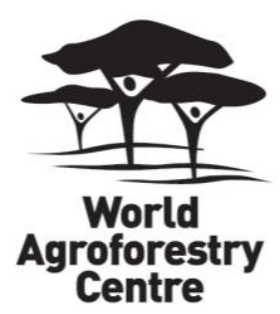

\section{Correct citation:}

Martini E, Tarigan J, Purnomosidhi P, Prahmono A, Surgana M, Setiawan E, Megawati, Mulyoutami E, Meldy BW, Syamsidar, Talui R, Janudianto, Suyanto, Roshetko JM. 2013. Seri Agroforestri dan Kehutanan di Sulawesi: Kebutuhan penyuluhan agroforestri pada tingkat masyarakat di lokasi proyek AgFor di Sulawesi Selatan dan Tenggara, Indonesia. Working paper 168. Bogor, Indonesia: World Agroforestry Centre (ICRAF) Southeast Asia Regional Program. 44p. DOI: 10.5716/WP13044.PDF.

Titles in the Working Paper Series aim to disseminate interim results on agroforestry research and practices and stimulate feedback from the scientific community. Other publication series from the World Agroforestry Centre include: Agroforestry Perspectives, Technical Manuals and Occasional Papers.

Published by the World Agroforestry Centre

Southeast Asia Regional Program

PO Box 161, Bogor 16001

Indonesia

Translated by Ariyantri E. Tarman

Tel: +62 2518625415

Fax: +62 2518625416

Email: icraf-indonesia@cgiar.org

Website: http://worldagroforestry.org/regions/southeast_asia

(C) World Agroforestry Centre 2013

Working Paper 168

\section{Photos:}

The views expressed in this publication are those of the author(s) and not necessarily those of the World Agroforestry Centre.

Articles appearing in this publication may be quoted or reproduced without charge, provided the source is acknowledged.

All images remain the sole property of their source and may not be used for any purpose without written permission of the source. 


\section{Tentang Penulis}

Endri Martini telah bekerja di ICRAF sejak 2002 pada beragam isu agroforestri mulai dari konservasi keanekaragaman hayati, pembayaran jasa lingkungan, dan pengembangan kapasitas para petani. Sekarang ini dia bekerja di ICRAF sebagai spesialis penyuluhan agroforestri. Dia mendapatkan gelar sarjana S1 di bidang Kehutanan dan gelar sarjana S2 di Sumber Daya Alam dan Pengelolaan Lingkungan.

Jusupta Tarigan bekerja di ICRAF sejak 2005 hingga 2012 pada isu-isu agroforestri seperti pengembangan kapasitas para petani dan kemitraan beragam pemangku kepentingan dalam isu sekuestrasi karbon. Dia sekarang bekerja untuk organisasi NTFP. Dia mendapatkan gelar sarjana S1 di bidang Kehutanan. Ketika penelitian ini dilakukan, Jusupta adalah koordinator lapangan di lokasi AgFor Sulawesi Tenggara.

Pratiknyo Purnomosidhi telah bekerja untuk ICRAF selama bertahun-tahun di isu-isu agroforestri mengenai konservasi tanah dan pembangunan pembibitan petani skala kecil. Dia sekarang bekerja di ICRAF sebagai koordinator lapangan untuk proyek AgFor Sulawesi Selatan. Dia mendapatkan gelar sarjana S1 dan S2 di bidang Ilmu Tanah.

Andi Prahmono bekerja di ICRAF sejak 1997 pada isu-isu agroforestri mengenai pengelolaan kebun dan pembibitan, dan pengembangan kapasitas petani. Dia sekarang bekerja di ICRAF sebagai Spesialis Agroforestri untuk proyek AgFor di Sulawesi Selatan.

Mulus Surgana bekerja di ICRAF sejak 2007 di isu-isu agroforestri mengenai pengelolaan pembibitan dan pengembangan kapasitas petani. Dia sekarang bekerja di ICRAF sebagai Spesialis Agroforestri untuk proyek AgFor di Sulawesi Selatan.

Anang Setiawan bekerja di ICRAF sejak 2007 di isu-isu agroforestri mengenai pengelolaan pembibitan dan pengembangan kapasitas petani. Dia sekarang bekerja di ICRAF sebagai Spesialis Agroforestri untuk proyek AgFor di Sulawesi Selatan. Dia mendapatkan gelar sarjana S1 di bidang Kehutanan. 
Megawati bekerja di ICRAF sejak 2012 di isu-isu agroforestri mengenai pengelolaan pembibitan. Dia sekarang bekerja di ICRAF sebagai Spesialis Petani untuk proyek AgFor di Sulawesi Selatan. Dia mendapatkan gelar sarjana S1 di bidang Biologi.

Elok Mulyoutani memulai penelitiannya di World Agroforestry Centre (ICRAF) kantor regional Asia Tenggara, berfokus pada kearifan lokal pada bidang ekologi dan sistem pertanian pada 2003. Dia bergelar sarjana S1 Antropologi dari Universitas Padjadjaran Bandung, Indonesia, dan sekarang sedang menyelesaikan program Magister Sosiologi Pedesaan di Institut Pertanian Bogor. Fokus penelitiannya sekarang adalah isu sosial demografi dan populasi yang lebih luas, mengkhususkan pada isu-isu gender.

Badri Dwi Meldy bekerja sebagai pengumpul data (enumerator) untuk studi ini di Sulawesi Selatan. Saat ini dia masih berkuliah di Fakultas Peternakan Universitas Hasanuddin, Makassar, Sulawesi Selatan.

Syamsidar bekerja sebagai pengumpul data untuk studi ini di Sulawesi Selatan dan Tenggara. Dia mendapatkan gelar sarjana S1 di bidang Peternakan. Dia sekarang bekerja di perusahaan vaksinasi ayam di Bogor.

Rahma Talui bekerja sebagai pengumpul data untuk studi ini di Sulawesi Tenggara. Dia mendapatkan gelar sarjana S1 di bidang Hukum. Dia sekarang bekerja untuk Konsorsium Solidaritas Perempuan di Sulawesi Tenggara.

Janudianto mendapatkan gelar sarjana di Ilmu Tanah dari Fakultas Pertanian, IPB. Dia bekerja untuk ICRAF sejak 2005 di isu-isu agroforestri mengenai pengelolaan kebun dan pengembangan kapasitas petani. Sekarang ini dia bekerja sebagai Spesialis Pengelolaan Agroforestri di ICRAF. Dia bekerja dengan para petani, dalam bidang strategi mata pencaharian masyarakat, pengelolaan sistem agroforestri tradisional---spesialisasi di sistem agroforestri karet yang diperbaiki dan penilaian agroekologi keanekaragaman hayati di Sumatra, Kalimantan, dan Sulawesi.

Dr. Suyanto memiliki lebih dari 15 tahun pengalaman dalam pengelolaan sumber daya alami dan analisis institusional. Dia bekerja di ICRAF-Program Penelitian Regional Asia Tenggara berbasis di Indonesia sejak 1994, mengembangkan serangkaian keahlian di bidang sosioekonomi, ekonomi sumber daya alam, ekonometri, dan analisis institusional. Dia melakukan studi evolusi penguasaan lahan masyarakat asli dan pengelolaan sumber daya pohon di zona penyangga Taman Seblat Nasional 
Kerinci di Sumatra untuk desertasi doktoralnya. Dalam lima tahun terakhir, dia mengelola beberapa proyek penelitian terkait dengan perubahan iklim, dalam judul (1) Efficient and Fair ways of Avoiding Carbon Emissions in Indonesia's Forest Margins: next steps in Negotiation Support Systems" (Ford Foundation Project); (2) "Sustainable livelihood options and carbon rights: a basis for efficient and fair emission reduction in the Central Kalimantan Ex-Mega Rice Project" (AUSAID Project); (3) "Fair, Efficient and Sustainable Emission Reduction from Land Use in Indonesia (FESERLUI)" - (Packard Project); (4) “Accountability and lokal level initiative to reduce emission from deforestation and degradation in Indonesia" (ALLREDDI-EU Project). Dia sekarang memimpin unit analisis ekonomi dan kebijakan di ICRAF Indonesia.

James M. Roshetko adalah Senior Integrated Natural Resource Management Scientist di World Agroforestry Centre (ICRAF) dan Winrock International. Dia adalah Kepala ICRAF Unit Pohon dan Pasar Asia Tenggara dengan pengalaman 33 tahun, meliputi 16 tahun di Indonesia dan 27 tahun di Asia Selatan dan Tenggara. Dia sekarang bekerja sebagai Pimpinan Tim proyek Agroforestry and Forestry in Sulawesi: Linking Knowledge with Action yang didanai oleh CIDA. Minat penelitiannya berfokus pada sistem berbasis pohon yang dikelola petani skala kecil sebagai sistem pengelolaan pertanian dan sumber daya alam yang viabel danberkontribusi secara nyata pada tujuan ekonomi setempat juga lingkungan secara global. 


\section{Abstrak}

Studi penilaian penyuluhan agroforestri ini dilakukan sebagai bagian dari studi dasar yang dilaksanakan untuk mendukung program-program yang diimplementasikan di proyek Agroforestry and Forestry in Sulawesi: Linking Knowledge with Action ('proyek AgFor'), yang didanai oleh Canadian International Development Agency (CIDA). Tujuan studi ini adalah untuk mendaftarkan dan menganalisis praktik-praktik penyuluhan agroforestri yang ada dan sudah diimplementasikan di tingkat masyarakat, dan untuk mendaftarkan kebutuhan masyarakat dalam hal layanan penyuluhan agroforestri potensial yang bisa diimplementasikan di dalam proyek Agfor. Diskusi kelompok terarah (FGD) di tingkat masyarakat dilakukan untuk mengumpulkan informasi mengenai jenis prioritas dalam mata pecaharian setempat, kegiatan penyuluhan yang ada dan potensial, kebun percontohan, program kunjungan silang, kebutuhan pelatihan pemasaran, preferensi gender yang terkait dengan program penyuluhan, dan media komunikasi potensial yang digunakan dalam kegiatan penyuluhan. Hasil survei dasar ini dimanfaatkan untuk merancang dan mengimplementasikan kegiatan penyuluhan di proyek AgFor.

Kata kunci: CIDA, AgFor, penyuluhan petani, Sulawesi, agroforestri 


\section{Ucapan Terima Kasih}

Studi ini didanai oleh Canadian International Development Agency (CIDA) melalui proyek Agroforestry and Forestry in Sulawesi: Linking Knowledge with Action. Para penulis menghargai bantuan, kerjasama dan kontribusi masyarakat serta badan pemerintahan di Kabupaten Bantaeng, Bulukumba, Konawe, dan Kolaka. Para penulis juga ingin menyampaikan terima kasih kepada Robin N. Leslie dan Nyanda Smith untuk bantuan mereka dalam penyuntingan manuskrip ini, dan tim Desktop Technology and Publication di World Agroforestry Centre untuk tata letak manuskrip. 



\section{Daftar Isi}

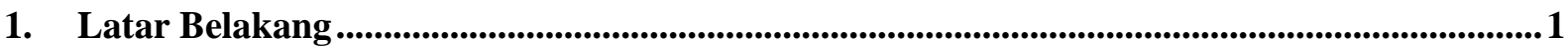

2. Pengumpulan data ..................................................................................................................

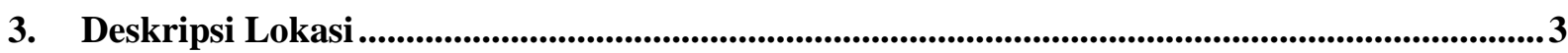

Kabupaten Bantaeng dan Bulukumba, Sulawesi Selatan .................................................................. 3

Kabupaten Kolaka dan Konawe, Sulawesi Tenggara ..............................................................

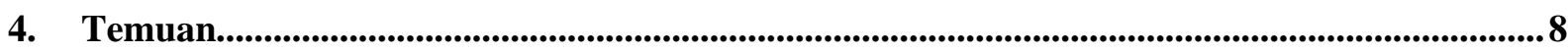

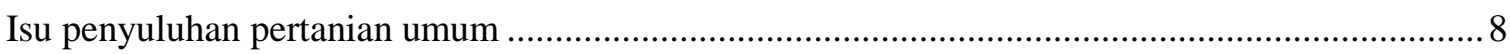

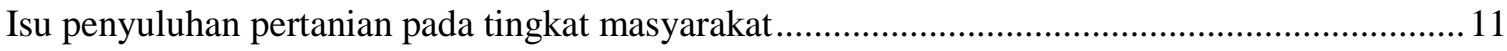

Isu penyuluhan agroforestri pada tingkat masyarakat di Sulawesi Selatan.................................... 12

Penyuluhan agroforestri pada tingkat masyarakat di Sulawesi Tenggara ..................................... 21

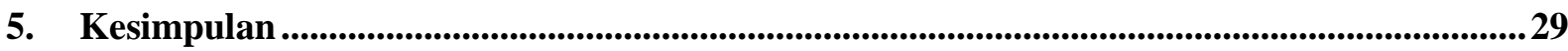

Daftar Pustaka ............................................................................................... Error! Bookmark not defined.

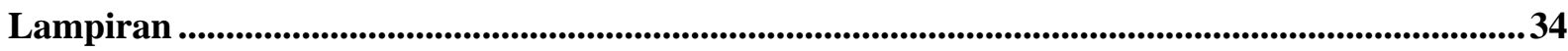

\section{Daftar Gambar}

Gambar 1. Struktur Organisasi Penyuluhan Pemerintah berdasarkan UU No.16/2006 9

\section{Daftar Tabel}

Tabel 1. Total area and production of ten predominant estate crops in Bulukumba and Bantaeng

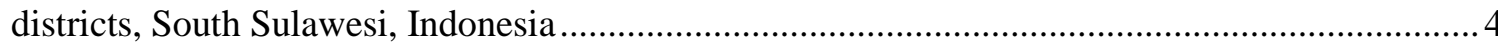

Tabel 2. Luas dan status hutan di Bantaeng dan Bulukumba, Sulawesi Selatan, Indonesia .................. 5

Tabel 3. Total luas lahan dan produksi sepuluh tanaman perkebunan utama di Kabupaten Kolaka

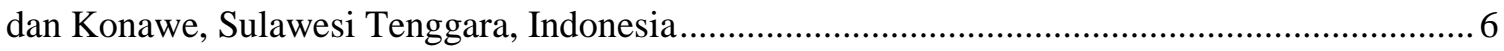

Tabel 4. Luas dan status hutan di Kabupaten Kolaka dan Konawe, Sulawesi Tenggara, Indonesia ..... 7

Tabel 5. Tanaman prioritas di Sulawesi Selatan oleh kelompok desa berdasarkan intervensi yang diharapkan oleh AgFor (E), kondisi pasar terkini (M), dan prioritas terkini dalam mata pencaharian setempat $(\mathrm{C})$

Tabel 6. Topik potensial untuk kegiatan penyuluhan di kelas pada proyek AgFor di Sulawesi Selatan

Tabel 7. Tipe pelatihan yang diharapkan dilakukan di masing-masing desa proyek AgFor Sulawesi Selatan. 
Tabel 8. Lahan percontohan petani yang pernah ada dan yang diharapkan di desa-desa proyek AgFor Sulawesi Selatan ....

Tabel 9. Peringkat efektivitas media komunikasi untuk penyuluhan pertanian di Sulawesi Selatan ...21

Tabel 10. Tanaman prioritas di Sulawesi Tenggara oleh kelompok desa berdasarkan intervensi yang diharapkan oleh AgFor (E), kondisi pasar terkini (M), dan prioritas terkini dalam mata pencaharian setempat $(\mathrm{C})$.

Tabel 11. Topik potensial untuk kegiatan penyuluhan di kelas pada proyek AgFor di Sulawesi Tenggara.

Tabel 12. Tipe pelatihan yang diharapkan di tingkat desa melalui layanan penyuluhan AgFor di Sulawesi Tenggara

Tabel 13. Lahan percontohan petani yang pernah ada dan yang diharapkan di desa-desa proyek AgFor Sulawesi Tenggara.

Tabel 14. Peringkat efektivitas media komunikasi untuk penyuluhan pertanian di Sulawesi Tenggara

Tabel 15. Topik prioritas untuk pelatihan proyek AgFor yang diminta oleh para petani di Sulawesi Selatan dan Tenggara..... 31 


\section{Latar Belakang}

Proyek Agroforestry and Forestry in Sulawesi: Linking Knowledge with Action (dirujuk sebagai proyek AgFor) didanai oleh Canadian International Development Agency (CIDA). Proyek ini diimplementasikan oleh World Agroforestry Centre dan para mitra dari 2011 hingga 2016 (Roshetko et al. 2012). Tujuan proyek Agfor ini adalah untuk meningkatkan sistem agroforestri yang adil dan berkelanjutan, serta meningkatkan sistem mata pencaharian kehutanan untuk masyarakat pedesaan di tiga provinsi di Sulawesi. Tujuan ini melingkupi isu-isu: kesadaran dan akses akan sumber daya alam yang membaik; perbaikan keahlian pertanian; pembangunan mekanisme tata kelola yang adil dan partisipatif; dan pembangunan pengelolaan lahan dan ekosistem yang berkelanjutan dan terpadu.

Di proyek AgFor, pendekatan penyuluhan agroforestri berbasis petani, seperti yang dicerminkan oleh hasil spesifik dari proyek ini, akan diimplementasikan untuk memberdayakan para petani baik lakilaki maupun perempuan dalam hal: i) meningkatkan dan meragamkan produktivitas dan profitabilitas sistem berbasis pohon para petani; ii) memperkuat kapasitas petani untuk meraih peluang pasar yang nyata; dan iii) meningkatkan kemungkinan keberlanjutan hasil kegiatan setelah proyek berakhir. Di tempat lain di Indonesia, kegiatan penyuluhan agroforestri berbasis petani digunakan untuk meningkatkan penghidupan masyarakat setempat melalui pembentukan badan usaha (Roshetko et al. 2007a), dan untuk membangun alternatif mata pencaharian yang berkelanjutan yang berkontribusi pada peningkatan kesejahteraan masyarakat setempat dan memperbaiki strategi konservasi keanekaragaman hayati (Roshetko et al. 2007b, Martini et al. 2007).

Maka dari itu, untuk mendukung implementasi layanan penyuluhan pada proyek AgFor, dilakukan penilaian kebutuhan penyuluhan agroforestri di tingkat masyarakat. Tujuan penilaian kebutuhan ini adalah: i) mendaftarkan dan menganalisis praktik-praktik penyuluhan agroforestri yang ada dan sudah diimplementasikan di tingkat masyarakat; dan ii) mendaftarkan kebutuhan masyarakat mengenai layanan penyuluhan agroforestri yang potensial dan bisa diimplementasikan di proyek AgFor. Hasil survei dasar ini bermanfaat dalam merancang, mengimplementasikan, dan menganalisis efektivitas pendekatan penyuluhan di dalam proyek AgFor. 


\section{Pengumpulan data}

Penilaian dilakukan dari Maret hingga April 2012 di empat kabupaten proyek AgFor---dua di Sulawesi Selatan (Bantaeng dan Bulukumba) dan dua di Sulawesi Tenggara (Konawe dan Kolaka). Diskusi dengan para penyuluh dilakukan di tingkat kabupaten. Di tiap kabupaten, tantangan dan kesempatan terkini yang dihadapi kegiatan penyuluhan di tingkat pemerintah didiskusikan dengan para pemangku kepentingan di Dinas Kehutanan dan Perkebunan, Dinas Pertanian, Badan Ketahanan Pangan dan Penyuluhan di Sulawesi Selatan, dan Badan Penyuluhan Pertanian Peternakan dan Kehutanan di Sulawesi Tenggara.

Penilaian kebutuhan dalam penyuluhan agroforestri dilakukan melalui diskusi kelompok terarah (focus group discussions-FGD) di tingkat desa. Di tiap desa, FGD dilakukan dengan memisahkan laki-laki dan perempuan, dan jumlah partisipan berkisar antara 5-12 orang per kelompok. Informasi mengenai kegiatan penyuluhan agroforestri yang ada dan yang diharapkan dikumpulkan selama diskusi berjalan. Desa-desa dipilih secara acak, diambil dari daftar desa proyek.

Di Sulawesi Selatan, dari 13 desa proyek, delapan desa dijadikan sampel untuk survei: empat desa di Kabupaten Bantaeng (Kayu Loe, Bonto Karaeng, Pattaneteang, dan Campaga) dan empat desa di Kabupaten Bulukumba (Balang Pesoang, Tana Toa, Tugondeng, dan Borong Rappoa). Desa yang disurvei dikategorikan ke dalam empat kelompok: i) kelompok desa berlahan terdegradasi (Kayu Loe dan Bonto Karaeng); ii) kelompok desa berbasis agroforestri (AF) di Bulukumba atau AF Bulukumba (Borong Rappoa dan Balang Pesoang); iv) kelompok desa berbasis kayu (Tana Toa dan Tugondeng).

Di Sulawesi Tenggara dari 14 desa proyek, sembilan desa dijadikan sampel untuk survei: empat desa di Kabupaten Kolaka (Tasahea, Simbune, Lamunde, dan Taosu) dan lima desa di Kabupaten Konawe (Wonua Hoa, Anggawo, Ambondiaa, Unit Pelaksana Teknis [UPT] Asinua Jaya, dan Lawonua). Desa- desa ini dikelompokkan ke dalam empat kategori berdasarkan proporsi masyarakat pendatang setempat di desa: i) kelompok desa lokal (Taosu, Ambondiaa, Lamunde, Simbune); ii) kelompok desa campuran antara pendatang/transmigran lokal dan lama (Tasahea); iv) kelompok desa transmigran baru (UPT Asinua Jaya [Lasao]). 


\section{Deskripsi Lokasi}

\section{Kabupaten Bantaeng dan Bulukumba, Sulawesi Selatan}

Ada 23 kabupaten di Sulawesi Selatan di mana masyarakatnya tergantung pada produk pertanian untuk mata pencaharian mereka. Dibandingkan provinsi lain di Sulawesi, Sulawesi Selatan lebih berkembang dan memiliki sistem-sistem pertanian yang lebih intensif, yang cenderung lebih banyak ditemukan di sebelah utara daripada selatan provinsi ini. Oleh karena itu, proyek AgFor, yang berfokus pada agroforestri dan kehutanan, memilih dua kabupaten di bagian selatan provinsi Sulawesi Selatan sebagai lokasi proyek, yaitu Kabupaten Bulukumba dan Bantaeng.

Ibu kota Kabupaten Bantaeng dan Bulukumba hanya terpisah $30 \mathrm{~km}$. Daerah aliran sungai (DAS) Bijawang terbentang di antara kedua kota ini. Di kedua kabupaten, ketinggian tempat bervariasi antara $0 \mathrm{~m}$ hingga $1.000 \mathrm{~m}$ di atas permukaan laut (mdpl), kondisi iklim di kedua kabupaten relatif sama dengan curah hujan bervariasi antara 1.500 hingga $3.000 \mathrm{~mm}$ per tahun. Namun, kondisi tanahnya berbeda, terutama untuk kecamatan Bonto Bahari yang berlokasi di bagian timur Bulukumba, dengan topografi didominasi oleh karst. Di bagian timur Bulukumba dan barat Bantaeng, berkurangnya ketersediaan air menjadi masalah lingkungan yang nyata.

Kabupaten Bulukumba memiliki sepuluh kecamatan dengan jumlah penduduk sebanyak 390.543 jiwa (berdasarkan data 2008) dan terdiri dari suku Makassar dan Bugis. Bahasa daerah adalah Makassar, Bugis, dan Konjo. Berdasarkan data statistik 2008, 25\% dari total penduduk di Kabupaten Bulukumba bisa dikategorikan miskin. Kecamatan Kajang dan Herlang adalah daerah termiskin di Kabupaten Bulukumba.

Bantaeng memiliki delapan kecamatan dengan jumlah penduduk 176.699 jiwa (berdasarkan data 2009) dan didominasi oleh suku Makassar di barat dan suku Bugis di timur. Walaupun bahasa Indonesia adalah bahasa nasional, masyarakat di daerah terpencil cenderung menggunakan bahasa daerah, terutama Makassar. Berdasarkan data statistik 2010, 38\% populasi total di Bantaeng bisa dikategorikan miskin. Sinoa, Uluere, dan Pajukukang adalah tiga kecamatan termiskin di Kabupaten Bantaeng. 
Produk pertanian di Sulawesi Selatan bervariasi tergantung dari daerah produksi. Berdasarkan total luas tutupan lahan, ada lima komoditas perkebunan utama di Kabupaten Bulukumba yaitu kakao, kelapa, cengkeh, kopi, dan lada; sedangkan di Bantaeng adalah jagung, kakao, kopi, cengkeh, dan kelapa (Tabel 1). Jagung lebih banyak ditemukan di Bantaeng, sementara untuk komoditas lada lebih banyak ditemukan di Bulukumba jika dibandingkan di Bantaeng. Dulu di Bulukumba, kapas termasuk tanaman utama, tetapi sekarang perkebunan kapas ditutup karena masalah modifikasi genetik varietas kapas yang digunakan. Selain kapas, perkebunan karet (PT. London Sumatra) beroperasi di Bulukumba sejak 1970-an.

Tabel 1. Total area and production of ten predominant estate crops in Bulukumba and Bantaeng districts, South Sulawesi, Indonesia

\begin{tabular}{lcccc}
\hline \multirow{2}{*}{ Tanaman } & \multicolumn{2}{c}{ Total luas lahan (ha) } & \multicolumn{2}{c}{ Total Produksi (ton tahun ${ }^{-1}$ ) } \\
\cline { 2 - 5 } & Bulukumba & Bantaeng & Bulukumba & Bantaeng \\
\hline Kakao & 4200 & 2894 & 3221,5 & 853,8 \\
\hline Kemiri & 55 & 2 & 21,0 & 181,1 \\
\hline Kacang mete & 405 & 325 & 403,0 & 287,6 \\
\hline Cengkeh & 2138 & 636 & 1435,0 & 314,7 \\
\hline Kelapa & 6966 & 355 & 2956,7 & 1470 \\
\hline Kopi & 2084 & 2847 & 963.6 & 292,8 \\
\hline Kapas & 369 & & 19049,0 & 93822,0 \\
\hline Kapuk (Ceiba petandra) & 17 & 333 & & 5,3 \\
\hline Jagung & 1162 & 15920 & 751,6 & 5,0 \\
\hline Lada & 100 & 35 & 35,0 & \\
\hline Tembakau & & & & \\
\hline
\end{tabular}

Sumber: BPS Bantaeng (2010), BPS Bulukumba (2010)

Sulawesi Selatan memiliki luas hutan paling sedikit dibandingkan dengan provinsi lain di Sulawesi, dikarenakan oleh tingkat kepadatan penduduk yang tinggi dan kegiatan pertanian yang intensif.

Namun, di beberapa daerah, masih ada hutan negara dan hutan rakyat, terutama di dalam dan di dekat area hutan lindung. Di Bantaeng dan Bulukumba, hutan negara bisa ditemukan di beberapa kecamatan, mencapai luas sekitar 4.721,5 ha di Bulukumba dan 7.417,5 ha di Bantaeng (Tabel 2). Beberapa kecamatan di Bulukumba (Herlang, Kajang, Ujung Bulu, Ujung Loe) memproduksi kayu dari kebun agroforestri mereka, terutama digunakan untuk membangun perahu. Bulukumba terkenal dengan industri pembangunan perahu phinisi tradisional mereka. PT Palopo Alam Lestari (PAL) juga memasok kayu dari Bulukumba untuk dikonversi menjadi kayu lapis (plywood). 
Tabel 2. Luas dan status hutan di Bantaeng dan Bulukumba, Sulawesi Selatan, Indonesia

\begin{tabular}{|c|c|c|c|c|c|c|}
\hline \multirow[b]{2}{*}{ Kabupaten } & \multirow[b]{2}{*}{ Kecamatan } & \multicolumn{5}{|c|}{ Luas hutan (ha) } \\
\hline & & $\begin{array}{l}\text { Hutan } \\
\text { Lindung }\end{array}$ & $\begin{array}{c}\text { Hutan } \\
\text { produksi } \\
\text { terbatas }\end{array}$ & $\begin{array}{c}\text { Hutan } \\
\text { produksi }\end{array}$ & $\begin{array}{l}\text { Hutan } \\
\text { rakyat }\end{array}$ & $\begin{array}{c}\text { Hutan } \\
\text { kota }\end{array}$ \\
\hline \multirow{4}{*}{ Bulukumba } & Kindang & 2522.70 & 544 & & & \\
\hline & Rilau ale & & & 675 & & \\
\hline & Bulukumpa & 648.88 & & & & \\
\hline & Kajang & & 331 & & & \\
\hline \multirow{4}{*}{ Bantaeng } & Tompobulu & 702 & & & 2500 & \\
\hline & Eremerasa & 14 & 419 & 355 & 800 & \\
\hline & Bantaeng & & & 364 & 800 & 3.5 \\
\hline & Sinoa & & & 710 & 750 & \\
\hline
\end{tabular}

Sumber: BPS Bantaeng (2010), BPS Bulukumba (2010)

\section{Kabupaten Kolaka dan Konawe, Sulawesi Tenggara}

Sulawesi Tenggara adalah daerah yang lebih lambat berkembang jika dibandingkan dengan provinsi lain di Sulawesi. Berdasarkan data statistik 2009, pertanian memberikan kontribusi 35\% bagi Produk Domestik Regional Bruto (PDRB) Sulawesi Tenggara. Pada tahun 2010, provinsi ini dibagi menjadi sepuluh kabupaten. Untuk Sulawesi Tenggara, isu daerah aliran sungai (DAS) menjadi topik utama yang dijadikan oleh proyek AgFor untuk memilih kabupaten. DAS Konaweha yang merupakan DAS terbesar di Sulawesi Tenggara, melintasi Kabupaten Konawe dan Kolaka, dua kabupaten ini dipilih sebagai daerah proyek di provinsi tersebut.

Kabupaten Kolaka dan Konawe adalah dua kabupaten tertua di Sulawesi Tenggara dan sejak 2006 telah dipecah dalam beberapa kabupaten---Kolaka dibagi menjadi Kabupaten Kolaka Selatan, Kolaka, dan Kolaka Utara; sementara Konawe dibagi menjadi Kabupaten Konawe Selatan, Konawe, dan Konawe Utara. Area Kolaka memiliki rentang ketinggian tempat dari 0 hingga 1.400 mdpl dengan curah hujan 2.500 hingga $3.500 \mathrm{~mm}$ per tahun. Tipe tanah bervariasi dari Podzolik merah kuning, Podzolik coklat abu, Podzolik, Litosol, Regosol, tanah alluvial, Renzina, dan tanah Mediterania merah kuning. Ketinggian tempat di Konawe mirip dengan rentang di Kolaka, dari-mulai 0 hingga 1.000 mdpl, dengan curah hujan 1.500 hingga 3.000 mm per tahun. Kondisi tanah di Konawe berbeda dengan Kolaka, walaupun kedua kabupaten ini terletak berdekatan. 
Konawe memiliki 26 kecamatan dengan total penduduk 224.345 jiwa (berdasarkan data BPS 2007). Tolaki adalah suku asli di Konawe. Namun, sekarang, program transmigrasi (baik dari pemerintah atau sukarela) mengubah Konawe menjadi daerah multisuku dengan pendatang dari Sulawesi Selatan (Bugis dan Toraja), Jawa, Bali, dan Lombok. Oleh karena itu, bahasa nasional Indonesia lebih banyak digunakan dalam percakapan sehari-hari. Bahasa daerah hanya digunakan di antara masyarakat dari suku yang sama. Sekitar 60\% dari total penduduk Konawe dapat dikategorikan miskin. Masalah kemiskinan juga tercermin dari infrastruktur yang buruk (terutama jalan, suplai listrik, dan air bersih), yang berdampak pada tingginya biaya pemasaran produk pertanian. Biaya pemasaran yang lebih tinggi menyebabkan harga produk petani yang lebih murah.

Kolaka memiliki 14 kecamatan dengan jumlah penduduk 262.211 jiwa (berdasarkan data 2005). Kolaka juga terdiri dari suku yang beragam, dengan suku asli Tolaki dan pendatang dari Bugis, Toraja, dan Bali. Bahasa Indonesia adalah bahasa yang digunakan dalam percakapan sehari-hari. Infrastruktur di Kolaka lebih maju dibandingkan dengan Konawe. Selain pertanian, pertambangan juga memberikan kontribusi ke PDRB Kolaka. Menurut data BPS 2005, sekitar 30\% dari total jumlah penduduk dikategorikan miskin.

Tabel 3. Total luas lahan dan produksi sepuluh tanaman perkebunan utama di Kabupaten Kolaka dan Konawe, Sulawesi Tenggara, Indonesia

\begin{tabular}{lcccc}
\hline \multirow{2}{*}{ Tanaman } & \multicolumn{2}{c}{ Total Luas Lahan (ha) } & \multicolumn{2}{c}{ Total Produksi (ton tahun ${ }^{-1}$ ) } \\
\cline { 2 - 5 } & Kolaka & Konawe & Kolaka & Konawe \\
\hline Kakao & 61647 & 14796 & 21961,7 & 5406,5 \\
\hline Lada & 1782 & 3653 & 1237,8 & 1179,5 \\
\hline Kelapa & 1461 & 7474 & 809,6 & 3226,0 \\
\hline Kopi & 1056 & 1724 & 693,1 & 403,4 \\
\hline Kacang mete & 856 & 11910 & 51,3 & 5085,1 \\
\hline Sagu & 448 & 2081 & 2095,2 & 2004,4 \\
\hline Kemiri & 402 & 456 & 741,9 & 108,9 \\
\hline Cengkeh & 291 & 778 & 13,1 & 131,2 \\
\hline Vanili & 269 & & 13,2 & 75,8 \\
\hline Melinjo & 58 & 203 & 7,1 & 44,5 \\
\hline Kapuk & & 259 & & \\
\hline
\end{tabular}

Sumber: BPS Kolaka (2010), BPS Konawe (2008) 
Selama sepuluh tahun terakhir di Sulawesi Tenggara, kakao, kacang mete, dan kelapa menjadi tiga tanaman perkebunan utama yang memberikan kontribusi ke PDRB tingkat provinsi. Di Konawe dan Kolaka, kakao menjadi tanaman perkebunan utama selain lada dan kelapa (Tabel 3). Kacang mete bukan komoditas utama di Kolaka dan Konawe, karena mete lebih banyak dihasilkan di Kabupaten Buton. Dibandingkan dengan Konawe, Kolaka memiliki luas lahan untuk budi daya kakao yang lebih besar, kemungkinan besar karena lahan di Kolaka lebih cocok untuk kakao dan juga karena penelitian dan pengembangan yang berfokus pada kakao di Kolaka (contohnya perkebunan kakao PT Haspram di Kecamatan Ladongi). Kopi dan sagu juga termasuk ke dalam lima tanaman perkebunan utama teratas di kedua kabupaten, yang ditanam terutama untuk konsumsi masyarakat sendiri dan untuk dijual. Sagu adalah makanan utama suku Tolaki dan juga masyarakat pendatang.

Hutan negara di Sulawesi Tenggara masih relatif utuh di area yang masih belum terkena dampak transmigrasi atau penebangan hutan ilegal. Hutan negara di Konawe meliputi $60 \%$ area total, sementara di Kolaka, hutan negara mencakup 90\% area total (Tabel 4). Produk hutan yang penting untuk mata pencaharian masyarakat setempat adalah kayu, rotan, dan madu. Di beberapa bagian kabupaten, area hutan diakui berada di bawah hak ulayat dan dikelola oleh klan individual atau keluarga di suku Tolaki.

Tabel 4. Luas dan status hutan di Kabupaten Kolaka dan Konawe, Sulawesi Tenggara, Indonesia

\begin{tabular}{lcc}
\hline \multirow{2}{*}{ Status hutan } & \multicolumn{2}{c}{ Luas hutan (ha) } \\
\cline { 2 - 3 } & Konawe & Kolaka \\
\hline Area terlindungi (Suaka dan Pelestarian Alam) & 19096 & 78524 \\
\hline Hutan lindung & 214147 & 325418 \\
\hline Hutan produksi terbatas & 113613 & 129542 \\
\hline Hutan produksi & 84021 & 78548 \\
\hline Hutan produksi yang dikonversi & 36720 & 36185 \\
\hline Hutan konservasi & & 32289 \\
\hline Total & 463790 & 621077 \\
\hline
\end{tabular}

Sumber: BPS South East Sulawesi (2011) 


\section{Temuan}

Secara umum, isu penyuluhan pertanian pada tingkat provinsi, kabupaten, dan kecamatan relatif sama baik di Sulawesi Selatan dan Sulawesi Tenggara. Perbedaan isu penyuluhan di kedua provinsi AgFor ini lebih jelas terlihat di tingkat masyarakat (desa). Sehingga, hasil temuan di dalam laporan ini dibagi menjadi dua bagian: i) isu penyuluhan pertanian umum dan ii) isu penyuluhan pertanian dan agroforestri pada tingkat masyarakat.

\section{Isu penyuluhan pertanian umum}

Sejak 2007, sudah terjadi restrukturisasi institusi penyuluhan pemerintah di Indonesia. Berdasarkan UU No. 16/2006, seluruh kantor penyuluhan pertanian, perikanan, dan kehutanan digabungkan menjadi badan pemerintahan mandiri berlokasi di tingkat provinsi dan kabupaten. Berdasarkan peraturan tersebut, institusi penyuluhan pemerintah di tingkat provinsi adalah Badan Koordinasi Penyuluhan, sementara di tingkat kabupaten dibentuk oleh kepala kabupaten menjadi Badan Pelaksana Penyuluhan (Gambar 1).

Sebelum 2007, penyuluh dipekerjakan di dinas-dinas yang berbeda berdasarkan keahlian mereka. Beberapa penyuluh, yang ditemui sewaktu survei, menjelaskan bahwa situasi menjadi lebih sulit untuk mereka setelah penggabungan tersebut karena setiap petugas diharuskan polivalen, yang berarti mereka harus memahami topik-topik lain di luar keahlian mereka masing-masing, contohnya penyuluh kehutanan harus juga memahami isu pertanian. Untuk mengatasi hal tersebut, pelatihan intensif untuk isu lintas sektor disediakan bagi para penyuluh di tingkat kabupaten. Dari sudut pandang administratif, alur administrasi menjadi lebih rumit sesudah penggabungan. Alhasil, implementasi UU No. 16/2006 mungkin harus ditinjau ulang untuk meningkatkan efektivitas layanan penyuluhan.

Tantangan lain yang ditemui dalam kegiatan penyuluhan pemerintah adalah kurangnya jumlah penyuluh. Tantangan ini ditemukan di semua lokasi proyek AgFor, terutama mengenai penyuluh kehutanan. Untuk mengatasi masalah ini, pemerintah mempekerjakan penyuluh paruh waktu untuk memenuhi kebutuhan proyek tertentu, contohnya proyek Kebun Bibit Rakyat (KBR) yang dilakukan oleh Departemen Kehutanan untuk menyediakan pembibitan pohon yang dikelola masyarakat untuk program rehabilitasi. 
Pemerintah pusat: Badan Penyuluhan di bawah koordinasi Kementerian dan Komisi

Penyuluhan Nasional

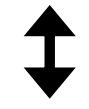

Tingkat provinsi: Badan Koordinasi Penyuluhan di bawah koordinasi gubernur dan Komisi Penyuluhan Provinsi

\section{$\uparrow$}

Tingkat kecamatan: Balai Penyuluhan di bawah koordinasi kepala Badan Pelaksana Penyuluhan di tingkat kabupaten

\section{$\uparrow$}

Tingkat desa: Program satu penyuluh untuk satu desa, dengan Pos Penyuluhan sebagai pusat layanan penyuluhan di tingkat desa

Gambar 1. Struktur Organisasi Penyuluhan Pemerintah berdasarkan UU No.16/2006

Selain keterbatasan jumlah, penyuluh juga belum memiliki cukup motivasi dan keahlian untuk memfasilitasi penciptaan dan adopsi teknologi baru. Sebagian besar kegiatan penyuluhan masih didasarkan pada pendekatan atas-bawah dengan hanya ada beberapa penyuluh yang memiliki inisiatif untuk memberikan layanan penyuluhan secara proaktif kepada masyarakat. Maka, untuk meningkatkan motivasi para penyuluh dalam memberikan layanan, pemerintah mengadakan kompetisi tahunan untuk memilih penyuluh terbaik dari tingkat kabupaten hingga nasional. Kondisi jalan yang buruk dan kurangnya fasilitas menjadi dua aspek penting lain yang menjadi kendala bagi para penyuluh untuk memberikan layanan bagi petani.

Berdasarkan hasil diskusi, hubungan antara badan penyuluhan dengan badan penelitian juga dirasakan belum cukup. Badan penelitian, yang biasanya berlokasi di tingkat provinsi, memiliki tugas utama memproduksi hasil penelitian, sehingga institusi ini melakukan lebih sedikit kegiatan penyebaran hasil penelitian kepada para petani. Sedangkan badan penyuluhan, yang biasanya berkegiatan di tingkat kabupaten, memiliki tugas utama untuk menyebarkan hasil penelitian kepada para petani. 
Tantangan utama dalam konteks ini adalah masih kurangnya koordinasi di antara badan penelitian dan badan penyuluhan terutama dikarenakan lokasi kedua badan ini yang berjauhan. Pengecualian dapat dilihat di Balai Pengembangan Teknologi Pertanian (BPTP) yang melaksanakan penelitian langsung bersama petani, sehingga bisa langsung menyebarkan hasil penelitian dengan lebih efektif.

Di tingkat kabupaten, di antara keempat kabupaten, penyuluh di Bantaeng lebih banyak mengunjungi masyarakat, sementara rekan mereka di Konawe paling jarang mengunjungi petani. Ini terjadi mungkin karena Bantaeng memiliki area terkecil untuk dijangkau dibandingkan dengan tiga kabupaten proyek AgFor lainnya. Setiap Sabtu, penyuluh di Bantaeng berkumpul secara rutin di kantor penyuluhan kabupaten untuk berbagi pengalaman.

Isu badan penyuluhan di tingkat kecamatan berbeda dengan tingkat kabupaten, karena badan penyuluhan kecamatan tidak memiliki garis koordinasi langsung dengan kepala kecamatan. Maka, penyuluh tidak ditempatkan pada kantor kecamatan. Penyuluh di tingkat kecamatan ditempatkan di kantor Balai Penyuluhan Pertanian (BPP).

Setidaknya setiap dua minggu, penyuluh harus mengunjungi warga desa untuk konsultasi, juga membantu para petani mengembangkan proposal untuk pendanaan atau bantuan dari departemen di tingkat kabupaten. Namun, tidak semua penyuluh berinteraksi dengan para petani berdasarkan jadwal ini. Desa-desa di daerah terpencil dengan akses yang sulit (seperti di Kabupaten Konawe) jarang dikunjungi oleh penyuluh kabupaten.

Kebanyakan kepala kecamatan yang dikunjungi selama survei, mengeluhkan lemahnya koordinasi antara kepala kecamatan dan dinas-dinas di kabupaten, terutama mengenai isu bantuan untuk para petani. Pada era desentralisasi, bantuan dari dinas tingkat kabupaten diberikan langsung kepada para petani dan prosesnya difasilitasi oleh penyuluh. Maka, kepala kecamatan tidak memiliki otoritas untuk ikut campur dalam proses tersebut. Biasanya dinas tingkat kabupaten diharuskan memberitahu kepala kecamatan mengenai setiap program di dinas masing-masing melalui musyawarah perencanaan pembangunan (musrenbang) yang diadakan setiap tahun (yaitu pada Februari atau Maret).

Kebanyakan penyuluh kabupaten dan kecamatan mengharapkan proyek AgFor dapat membantu penyuluh pemerintah setempat untuk memperbaiki kapasitas mereka dalam pemberian layanan penyuluhan. Contohnya adalah dengan melibatkan setidaknya satu hingga dua penyuluh di desa proyek, dan meminta para penyuluh untuk berpartisipasi dalam proyek AgFor. Dengan demikian, 
diharapkan akan memudahkan proses koordinasi antara program layanan penyuluhan proyek AgFor dengan rencana penyuluhan strategis di tingkat kabupaten.

\section{Isu penyuluhan pertanian pada tingkat masyarakat}

Pada studi ini isu penyuluhan pertanian lebih banyak dibahas karena belum ada penyuluhan yang terfokus pada isu agroforestri. Di tingkat masyarakat, isu penyuluhan pertanian yang relevan dengan konteks agroforestri dieksplorasi pada diskusi kelompok terarah dengan para petani di tingkat desa. Informasi mengenai pembuatan prioritas tanaman untuk para petani, layanan penyuluhan, lahan percontohan, kunjungan silang, isu pemasaran, isu gender, dan media komunikasi, dikumpulkan dan dianalisis.

Tanaman yang dijadikan prioritas di desa proyek AgFor dianalisis melalui tiga perspektif yaitu berdasarkan:

- Produk yang bisa dipasarkan (M)---tanaman-tanaman penghasil produk yang dapat dipasarkan dan secara konsisten memberikan kontribusi pada mata pencaharian masyarakat setempat.

- Pilihan para petani berdasarkan kondisi terkini (C)---tanaman dipilih para petani karena dapat menyediakan sumber pendapatan dan dapat dikonsumsi sendiri.

- Ekspektasi para petani dalam program intervensi proyek (E)---tanaman yang nanti akan bisa memberikan kontribusi pada peningkatan mata pencaharian masyarakat setempat. Tanaman ini mungkin jenis baru atau jenis yang sudah ada dan memiliki prospek menjanjikan.

Layanan penyuluhan pertanian diklasifikasikan ke dalam dua tipe berbeda---kegiatan di kelas dan pelatihan. Para petani diminta mengidentifikasi tipe layanan penyuluhan yang sudah diterima dan tipe yang diharapkan akan diimplementasikan di proyek AgFor.

Informasi mengenai program lahan percontohan pertanian juga dikumpulkan, terutama karena lahan percontohan efektif dalam membantu proses adopsi teknologi baru yang diperkenalkan kepada para petani. Para petani cenderung mengadopsi teknologi yang sudah dipraktikkan atau terbukti bermanfaat. Maka, proyek AgFor tertarik untuk mendirikan lahan percontohan untuk memperbaiki pengelolaan pada kebun yang sudah ada dan untuk mendemonstrasikan jenis-jenis tanaman unggul baru pada lahan yang kosong. Partisipasi para petani di lahan percontohan bisa ditingkatkan dengan lahan percontohan yang dirancang secara bersama-sama. Oleh karena itu, lahan percontohan harus 
dirancang oleh para petani/pemilik lahan bersama dengan penyuluh, dan difasilitasi oleh staf proyek AgFor.

Kunjungan silang adalah kegiatan yang memungkinkan para petani untuk mengunjungi lokasi lain dan belajar lebih banyak dari mengamati dan berinteraksi langsung dengan petani lain atau pemangku kepentingan yang terkait. Kunjungan silang membantu para petani untuk membangun jaringan dengan pemangku kepentingan lain mengenai kepentingan yang mereka bagi bersama. Untuk itu, kunjungan silang akan diimplementasikan pada proyek AgFor.

Pemasaran adalah isu penting yang memengaruhi pendapatan petani dan memotivasi petani untuk memperbaiki pengelolaan tanaman mereka. Untuk itu, informasi mengenai kebutuhan pelatihan para petani untuk meningkatkan pengetahuan dan keahlian pemasarannya juga dikumpulkan pada survei ini.

Distribusi proporsi partisipasi antar jenis kelamin dalam layanan penyuluhan pertanian diamati dengan melakukan dua diskusi kelompok terarah di tiap desa---satu untuk perempuan, satu untuk lakilaki---dan membandingkan informasi yang didapatkan dari kedua kelompok.

Media komunikasi seperti televisi, radio, dan ponsel dalam layanan penyuluhan pertanian adalah elemen penting yang bisa melengkapi interaksi personal yang dilakukan antara penyuluh dengan petani. Para petani diminta dalam diskusi kelompok terarah untuk memberi peringkat pada daftar media komunikasi yang efektif untuk penyuluhan pertanian, yang mencakup CD/DVD, ponsel, majalah, koran, radio, dan televisi.

Informasi yang dikumpulkan dari diskusi kelompok terarah dalam konteks ini ditabulasikan di bagian selanjutnya. Perbandingan kebutuhan di Sulawesi Selatan dan Tenggara dirangkum pada bagian kesimpulan dari laporan ini.

\section{Isu penyuluhan agroforestri pada tingkat masyarakat di Sulawesi Selatan}

\section{Penetapan prioritas jenis tanaman di Sulawesi Selatan}

Berdasarkan kondisi pasar dan kondisi terkini, prioritas tanaman berbeda di antara kelompokkelompok desa (Tabel 5). Namun, terlepas dari kondisi mendasar tersebut, semua kelompok desa di Sulawesi Selatan memilih tanaman berumur pendek (seperti cabai, kubis, sayur-sayuran, labu, labu 
siam) sebagai prioritas pertama mereka. Dari semua kelompok desa, kelompok desa berbasis kayu memiliki perbedaan terbesar dalam prioritas jenis tanamannya, terutama karena daerah mereka berlokasi di dataran rendah (50-200 mdpl) dibandingkan dengan desa lain yang berada pada ketinggian 200-800 mdpl. Kelapa, jati, dan jati putih menjadi jenis tanaman prioritas yang mendukung mata pencaharian petani di kelompok desa berbasis kayu.

Tanaman pangan pokok seperti padi dan jagung juga penting sebagai sumber penghasilan dan untuk konsumsi masyarakat di kelompok desa berbasis kayu. Kelompok desa berlahan terdegradasi, kelompok desa AF-Banteng, dan kelompok desa AF-Bulukumba memiliki prioritas yang relatif sama--cengkeh, kakao, dan kopi. Kelompok desa berlahan terdegradasi juga memilih kemiri dan bambu yang tidak ditemukan di tempat lain. Jagung lebih penting ketimbang padi untuk kelompok desa berlahan terdegradasi, berlawanan dengan kelompok desa AF-Bantaeng dan kelompok desa AFBulukumba. Sebagai perbandingan, berbeda dengan desa lainnya, di kelompok desa AF-Bantaeng yang masih menjadikan Hasil Hutan NonKayu (HHNK) sebagai sumber untuk kayu bakar dan gula aren (dari Arenga pinnata) dan juga sebagai sumber pendapatan. Lada menjadi tanaman prioritas hanya di kelompok desa AF-Bulukumba.

Tabel 5. Tanaman prioritas di Sulawesi Selatan oleh kelompok desa berdasarkan intervensi yang diharapkan oleh AgFor (E), kondisi pasar terkini (M), dan prioritas terkini dalam mata pencaharian setempat (C)

\begin{tabular}{|c|c|c|c|c|c|c|c|c|c|c|c|c|}
\hline \multirow{3}{*}{ Tanaman } & \multicolumn{12}{|c|}{ Prioritas tanaman kelompok desa } \\
\hline & \multicolumn{3}{|c|}{$\begin{array}{c}\text { Lahan } \\
\text { terdegradasi }\end{array}$} & \multicolumn{3}{|c|}{ Lahan terdegradasi } & \multicolumn{3}{|c|}{ Lahan terdegradasi } & \multicolumn{3}{|c|}{ Lahan terdegradas } \\
\hline & $\mathbf{E}$ & C & $\mathbf{M}$ & E & C & $\mathbf{M}$ & E & C & $\mathbf{M}$ & E & C & $\mathbf{M}$ \\
\hline Kakao & 1 & 2 & 3 & 3 & 2 & 2 & 4 & 6 & 5 & 2 & 5 & 6 \\
\hline Cengkeh & 1 & 2 & 3 & 2 & 2 & 5 & 1 & 2 & 2 & & 10 & 8 \\
\hline Tanaman umur pendek & 5 & 1 & 1 & & 1 & 1 & & 1 & 1 & 6 & 1 & 4 \\
\hline Kopi & 9 & 2 & 8 & & 2 & 2 & 4 & 3 & 2 & & 10 & \\
\hline Kemiri & & 5 & 3 & & & & & & & & & \\
\hline Kelapa & & & & & & & & & & & 5 & 1 \\
\hline Lada & & & & & & & 4 & 6 & 5 & & & \\
\hline Karet & & & & & & & 8 & & & 1 & 1 & \\
\hline Pala & & & & 3 & 10 & & 1 & 3 & & & & \\
\hline Nilam & & & & 7 & & & & & & & & \\
\hline Gaharu & & & & 7 & & & 4 & 6 & & 6 & & \\
\hline Bambu & & 10 & 3 & & & & & & & & & \\
\hline HHNK & & & & & & 8 & & & & & & \\
\hline
\end{tabular}




\begin{tabular}{|c|c|c|c|c|c|c|c|c|c|c|c|c|}
\hline \multirow{3}{*}{ Tanaman } & \multicolumn{12}{|c|}{ Prioritas tanaman kelompok desa } \\
\hline & \multicolumn{3}{|c|}{$\begin{array}{c}\text { Lahan } \\
\text { terdegradasi }\end{array}$} & \multicolumn{3}{|c|}{ Lahan terdegradasi } & \multicolumn{3}{|c|}{ Lahan terdegradasi } & \multicolumn{3}{|c|}{ Lahan terdegradas } \\
\hline & $\mathbf{E}$ & C & $\mathbf{M}$ & E & C & $\mathbf{M}$ & $\mathbf{E}$ & C & $\mathbf{M}$ & $\mathbf{E}$ & C & $\mathbf{M}$ \\
\hline Padi & 5 & 10 & 8 & 1 & 2 & 2 & 8 & 6 & 5 & 2 & 5 & 2 \\
\hline Jagung & 1 & 5 & 2 & 3 & 10 & 8 & & 6 & & 2 & 5 & 2 \\
\hline \multicolumn{13}{|l|}{ Kayu-kayuan } \\
\hline Mahoni & & & & & & & 8 & & & 6 & & \\
\hline Jati putih & & & & & & & & & & & & 8 \\
\hline Jati & & & & & & & & & & & 5 & 6 \\
\hline Suren & & & & & & & 8 & & & & & \\
\hline Sengon & & 10 & & & & & & & & & 10 & \\
\hline \multicolumn{13}{|l|}{ Buah-buahan } \\
\hline Durian & 1 & 10 & & 7 & 2 & & 1 & 3 & 5 & 2 & 10 & \\
\hline Pisang & & 7 & 3 & & 8 & 5 & & 6 & 2 & & 1 & 4 \\
\hline Rambutan & 5 & 10 & & & 8 & & & 6 & 5 & 6 & 1 & 8 \\
\hline Duku & & & & & 2 & 5 & 8 & 6 & 5 & & & 8 \\
\hline Alpukat & & 7 & & & & & & & & & & \\
\hline Jeruk bali & & & & & & & & & & 6 & & \\
\hline Pepaya & & 10 & & & & & & & & & & \\
\hline Mangga & 5 & 10 & & & & & & & & 6 & & \\
\hline Manggis & & & & 3 & & & 8 & 6 & & & & \\
\hline Nangka & & 7 & 8 & & & & & & & & 10 & \\
\hline Lengkeng & & & & & & & & & & 6 & & \\
\hline
\end{tabular}

Catatan: 1 = prioritas tertinggi. $E=$ ekspektasi, $C=$ sekarang, $M=$ pasar, $H H N K=$ hasil hutan nonkayu

Berdasarkan potensi masa depan atau ekspektasi dari proyek AgFor, prioritas tanaman potensial sedikit berbeda di antara kelompok desa (Tabel 5). Hanya durian yang diprioritaskan sebagai tanaman potensial di semua kelompok desa, terutama karena harga buah yang mahal ( $R p 50.000-R p 150.000$, atau USD 5-15 per buah), yang meningkatkan motivasi para petani untuk menanam jenis durian berkualitas baik di lahan mereka. Cengkeh adalah tanaman potensial kedua yang dipilih karena harga cengkeh baru saja naik selama sepuluh tahun terakhir, mencapai Rp $200.000 \mathrm{~kg}^{-1}$ untuk bunga cengkeh kering. Namun, tidak semua kelompok desa memilih cengkeh, khususnya kelompok desa berbasis kayu yang berlokasi di dataran rendah.

Begitu pula halnya dengan kakao, karena harganya yang tinggi dan relatif stabil, kakao menjadi jenis potensial ketiga yang diminta semua petani di lokasi AgFor. Gaharu adalah jenis potensial menarik yang dipilih oleh para petani, walaupun petani tidak memiliki informasi atau pengalaman mengenai potensi pasar gaharu. Karet, kemiri, rambutan, dan mangga adalah jenis tanaman berbasis pohon 
potensial selanjutnya sesudah durian, cengkeh, dan kakao. Kelompok desa berbasis kayu, yang berlokasi dekat dengan perkebunan karet PT London Sumatra, memprioritaskan karet untuk intervensi proyek AgFor. Kelompok desa AF-Bulukumba juga memilih karet, walaupun karet bukan prioritas di kelompok desa berlahan terdegradasi dan kelompok desa AF-Bantaeng. Mahoni diprioritaskan oleh kelompok desa berbasis kayu dan kelompok desa AF-Bulukumba. Padi menjadi tanaman yang lebih prioritas daripada jagung di AF-Bantaeng, AF-Bulukumba, dan kelompok desa berbasis kayu. Sedangkan kelompok desa berlahan terdegradasi lebih memilih jagung. Jagung dan padi dipilih terutama karena keduanya merupakan tanaman pangan pokok di daerah itu.

Para petani memilih tanaman-tanaman ini untuk intervensi proyek AgFor karena kurangnya akses ke bahan tanam berkualitas baik, sekalipun sudah lebih dari 10 tahun pemerintah mengimplementasikan program distribusi bibit unggul untuk mengatasi masalah ini. Di kebanyakan desa proyek AgFor, pemerintah mendistribusikan bibit-bibit pohon berdasarkan permintaan petani setidaknya sekali setahun. Namun, badan pemerintahan hanya mendistribusikan bibit dan bahan tanam dari jenis-jenis tanaman yang tersedia pada saat petani meminta, baik itu jenis baru atau yang sudah dikenal baik. Badan pemerintahan terkadang kesulitan mendapatkan bibit-bibit yang diminta petani, biasanya karena ketidakcukupan informasi tempat untuk mendapatkan bahan tanam yang berkualitas, juga kurangnya sumber tanaman induk untuk jenis tanaman unggul yang berkualitas baik .Para petani juga merasa tidak memiliki cukup akses ke sumber bibit berkualitas baik dalam jumlah cukup. Dinas Pertanian, Dinas Perkebunan, dan Dinas Kehutanan adalah badan pemerintahan di tingkat kabupaten yang paling sering mendistribusikan bibit kepada kelompok petani yang mengajukan permintaan. Jenis tanaman yang biasanya diminta petani di Bantaeng dan Bulukumba adalah sayuran, buah, tanaman perkebunan, dan jenis-jenis pohon kayu, tergantung pada permintaan dan sumber daya yang tersedia (Lampiran 1).

\section{Layanan penyuluhan di Sulawesi Selatan}

Selama lima tahun terakhir di Sulawesi Selatan, para petani mendapatkan layanan penyuluhan melalui pelatihan (Lampiran 2) dan kegiatan di kelas (Lampiran 3) mengenai isu pertanian seperti budi daya sayuran, enten samping kakao, dan pembuatan kompos. Berdasarkan informasi yang disampaikan oleh partisipan, sampai saat ini partisipasi perempuan dalam kegiatan penyuluhan yang telah dilakukan bervariasi antara 0-80\% tergantung pada subjek penyuluhan. Partisipasi perempuan lebih tinggi dalam kegiatan penyuluhan untuk industri rumah tangga, produksi madu, dan produksi tekstil 
tradisional. Partisipasi perempuan rendah dalam kegiatan penyuluhan soal pemupukan dan kegiatan perawatan lahan lain.

Tabel 6. Topik potensial untuk kegiatan penyuluhan di kelas pada proyek AgFor di Sulawesi Selatan

\begin{tabular}{|c|c|c|c|c|}
\hline \multirow[b]{2}{*}{ Desa } & \multicolumn{4}{|c|}{ Topik } \\
\hline & $\begin{array}{c}\text { Teknik penanaman dan } \\
\text { perawatan tanaman }\end{array}$ & $\begin{array}{l}\text { Teknik penanaman dan } \\
\text { perawatan tanaman }\end{array}$ & $\begin{array}{l}\text { Teknik penanaman } \\
\text { dan perawatan } \\
\text { tanaman }\end{array}$ & $\begin{array}{c}\text { Teknik penanaman } \\
\text { dan perawatan } \\
\text { tanaman }\end{array}$ \\
\hline \multicolumn{5}{|c|}{ Kelompok desa berlahan terdegradasi } \\
\hline Kayu Loe & $\begin{array}{l}\text { Jagung, cengkeh, } \\
\text { bawang, kentang, kubis }\end{array}$ & & & Kuda, kambing \\
\hline $\begin{array}{l}\text { Bonto } \\
\text { Karaeng }\end{array}$ & $\begin{array}{l}\text { Jagung, padi, cengkeh, } \\
\text { pakan unggas, sayuran, } \\
\text { nilam, cabai, tomat }\end{array}$ & Kakao, cengkeh & Kakao & Unggas \\
\hline \multicolumn{5}{|c|}{ Kelompok desa AF-Bantaeng } \\
\hline Campaga & & & Kakao & Sapi, kuda, ikan \\
\hline Pattaneteang & $\begin{array}{l}\text { Padi, cengkeh, pala, } \\
\text { nilam, durian }\end{array}$ & Cengkeh & $\begin{array}{l}\text { Cara memilih } \\
\text { varietas jenis } \\
\text { unggul }\end{array}$ & \\
\hline \multicolumn{5}{|c|}{ Kelompok desa AF-Bulukumba } \\
\hline $\begin{array}{l}\text { Borong } \\
\text { Rappoa }\end{array}$ & Gaharu dan pala & $\begin{array}{l}\text { Pohon buah, sayuran, } \\
\text { padi, jagung }\end{array}$ & $\begin{array}{l}\text { Padi, jagung, } \\
\text { cengkeh, gaharu, } \\
\text { dan pala }\end{array}$ & \\
\hline $\begin{array}{l}\text { Balang } \\
\text { Pesoang }\end{array}$ & $\begin{array}{l}\text { Tanamanberjangka } \\
\text { pendek, cengkeh }\end{array}$ & Cengkeh & Cengkeh & Sapi, unggas, ikan \\
\hline \multicolumn{5}{|c|}{ Kelompok desa berbasis kayu } \\
\hline Tana Toa & Karet, padi, kakao & & & \\
\hline Tugondeng & $\begin{array}{l}\text { Pemangkasan pohon kayu } \\
\text { kakao; peremajaan kebun }\end{array}$ & Kakao dan pohon kayu & & \\
\hline
\end{tabular}

Diskusi kelompok terarah di tingkat desa mengungkapkan tidak ada perbedaan nyata antar kelompok desa dalam topik yang diharapkan diberikan pada penyuluhan di kelas oleh proyek AgFor di Sulawesi Selatan (Tabel 6). Teknik penanaman dan perawatan tanaman paling banyak diminta, kecuali di Campaga yang sudah menerima lebih banyak kegiatan penyuluhan di kelas dibandingkan dengan desa-desa lain. Penanggulangan hama dan penyakit dan identifikasi varietas tanaman berada di urutan selanjutnya, sementara pengelolaan hewan ternak menempati posisi terakhir. Tidak ada perbedaan nyata mengenai pilihan untuk topik kelas di antara kelompok desa. Namun, tiap desa memiliki jenis tanaman prioritas yang berbeda pada tiap topik penyuluhan. Contohnya, di kegiatan kelas mengenai teknik penanaman, petani di Borong Rappoa ingin fokus pada gaharu dan pala, sementara di Balang Pesoang para petani ingin fokus pada tanaman berjangka pendek dan cengkeh. 
Prioritas untuk tipe pelatihan yang diharapkan dilakukan melalui proyek AgFor juga tidak berbeda secara nyata di antara kelompok desa (Tabel 7). Kelompok desa AF-Bulukumba memiliki jumlah topik paling sedikit dibandingkan dengan kelompok desa lain, ingin memfokuskan pelatihan hanya pada perbanyakan tanaman secara vegetatif, penanggulangan hama dan penyakit, pupuk organik, dan pengaturan jarak pohon dalam agroforestri. Di kelompok desa berlahan terdegradasi, para petani ingin berfokus pada pelatihan tentang perbanyakan vegetatif, penanggulangan hama dan penyakit, pupuk organik, produksi madu, dan pengaturan jarak pohon di agroforestri. Di kelompok desa AF-Bantaeng, para petani memilih perbanyakan vegetatif, peremajaan kakao, penanggulangan hama dan penyakit, pupuk organik, pascapanen kakao, produksi madu, dan penilaian keberlanjutan lahan sebagai topik pelatihan. Sedangkan, kelompok desa berbasis kayu memilih perbanyakan vegetatif, peremajaan kakao, penanggulangan hama dan penyakit, pupuk organik, agroforestri karet, produksi madu, pengelolaan kebun rumah, dan pengaturan jarak pohon di agroforestri. 
Tabel 7. Tipe pelatihan yang diharapkan dilakukan di masing-masing desa proyek AgFor Sulawesi Selatan

\begin{tabular}{|c|c|c|c|c|c|c|c|c|c|c|}
\hline \multirow[b]{2}{*}{ Desa } & \multicolumn{10}{|c|}{ Topik-topik pelatihan yang diharapkan } \\
\hline & $\begin{array}{c}\text { Perbanyakan } \\
\text { vegetatif }\end{array}$ & $\begin{array}{c}\text { Peremajaan } \\
\text { kakao }\end{array}$ & $\begin{array}{l}\text { Penanggulangan } \\
\text { hama dan penyakit }\end{array}$ & $\begin{array}{l}\text { Pupuk } \\
\text { organik }\end{array}$ & $\begin{array}{l}\text { Agroforestri } \\
\text { karet }\end{array}$ & $\begin{array}{l}\text { Pascapanen } \\
\text { kakao }\end{array}$ & $\begin{array}{l}\text { Produksi } \\
\text { madu }\end{array}$ & $\begin{array}{l}\text { Pengelolaan } \\
\text { kebun } \\
\text { pekarangan }\end{array}$ & $\begin{array}{c}\text { Pengaturan jarak } \\
\text { pohon di } \\
\text { agroforestri }\end{array}$ & $\begin{array}{c}\text { Penilaian } \\
\text { kesesuaian } \\
\text { lahan }\end{array}$ \\
\hline \multicolumn{11}{|c|}{ Kelompok desa berlahan terdegradasi } \\
\hline Persentase total & 100 & 0 & 100 & 100 & 0 & 0 & 50 & 0 & 100 & 0 \\
\hline Kayu Loe & v & & $\mathrm{v}$ & $\mathrm{v}$ & & & $\mathrm{V}$ & & $v$ & \\
\hline Bonto Karaeng & $v$ & & $v$ & $\mathrm{v}$ & & & & & $v$ & \\
\hline \multicolumn{11}{|c|}{ Kelompok desa AF-Bulukumba } \\
\hline Persentase total & 100 & 0 & 50 & 50 & 0 & 0 & 0 & 0 & 50 & 0 \\
\hline Borong Rappoa & $v$ & & & $\mathrm{v}$ & & & & & $v$ & \\
\hline Balang Pesoang & $v$ & & $v$ & & & & & & & \\
\hline \multicolumn{11}{|c|}{ Kelompok desa AF-Bantaeng } \\
\hline Persentase total & 50 & 50 & 50 & 50 & 0 & 50 & 50 & 0 & 0 & 50 \\
\hline Campaga & & $v$ & $v$ & & & $v$ & V & & & \\
\hline Pattaneteang & v & & & $v$ & & & & & & $\mathrm{v}$ \\
\hline \multicolumn{11}{|c|}{ Kelompok desa berbasis kayu } \\
\hline Persentase total & 100 & 50 & 50 & 50 & 50 & 0 & 50 & 50 & 50 & 0 \\
\hline Tana Toa & $\mathrm{v}$ & & & $\mathrm{v}$ & $v$ & & & & & \\
\hline Tugondeng & v & v & v & & & & V & v & $v$ & \\
\hline
\end{tabular}




\section{Lahan percontohan di Sulawesi Selatan}

Berdasarkan hasil diskusi, lahan percontohan bukanlah hal umum di tingkat petani Sulawesi Selatan. Sebelumnya, sudah pernah didirikan beberapa lahan percontohan oleh badan pemerintahan (Tabel 8). Dari semua desa yang disurvei pada studi ini, hanya desa Balang Pesoang yang belum pernah memiliki lahan percontohan. Lahan percontohan yang sudah ada kebanyakan dikembangkan oleh Dinas Pertanian, badan pertanian milik pemerintah. Tanaman yang ditanam di lahan percontohan yang sudah ada kebanyakan sayur, kopi, kakao, padi, jagung, talas, dan beberapa jenis-jenis pohon kayu di area rehabilitasi lahan.

Tabel 8. Lahan percontohan petani yang pernah ada dan yang diharapkan di desa-desa proyek AgFor Sulawesi Selatan

\begin{tabular}{|c|c|c|c|c|c|}
\hline \multirow[b]{2}{*}{ Village } & \multicolumn{3}{|c|}{ Lahan percontohan yang pernah ada di desa } & \multicolumn{2}{|c|}{$\begin{array}{l}\text { Lahan percontohan yang diharapkan di } \\
\text { proyek AgFor }\end{array}$} \\
\hline & $\begin{array}{l}\text { Lahan } \\
\text { percontohan }\end{array}$ & $\begin{array}{l}\text { Lahan } \\
\text { percontohan } \\
\text { kebun }\end{array}$ & $\begin{array}{l}\text { Lahan } \\
\text { percontohan } \\
\text { pembibitan }\end{array}$ & Lahan percontohan & $\begin{array}{l}\text { han percontohan } \\
\text { bun }\end{array}$ \\
\hline \multicolumn{6}{|c|}{ Kelompok desa berlahan terdegradasi } \\
\hline Kayu Loe & 2010 & $\begin{array}{l}\text { Dinas } \\
\text { Pertanian }\end{array}$ & Talas Safira & \multicolumn{2}{|l|}{$\begin{array}{l}\text { Sistem campuran (cengkeh+ } \\
\text { kakao+kopi+kacang+bawan } \\
\text { g+stroberi+apel) }\end{array}$} \\
\hline Bonto Karaeng & 2011 & $\begin{array}{l}\text { Universitas } \\
\text { Hasanuddin }\end{array}$ & & \multicolumn{2}{|l|}{$\begin{array}{l}\text { Sistem campuran (jagung+ } \\
\text { durian+kopi+rambutan+ } \\
\text { kakao+cengkeh) }\end{array}$} \\
\hline \multicolumn{6}{|c|}{ Kelompok desa AF-Bantaeng } \\
\hline Campaga & 2011 & $\begin{array}{l}\text { Kelompok Tani } \\
\text { Nelayan Andalan }\end{array}$ & & $\begin{array}{l}\text { Mixed system (maize+ } \\
\text { coffee+cacao+cloves) }\end{array}$ & \\
\hline Pattaneteang & 2006 & Dinas Kehutanan & $\begin{array}{l}\text { Coffee; } \\
\text { timber trees }\end{array}$ & $\begin{array}{l}\text { Mixed system } \\
\text { (nutmeg+mangosteen+ } \\
\text { coffee) }\end{array}$ & $\begin{array}{l}\text { Nutmeg, } \\
\text { mangosteen, cacao }\end{array}$ \\
\hline \multicolumn{6}{|c|}{ Kelompok desa AF-Bulukumba } \\
\hline Borong Rappoa & 2011 & Dinas Pertanian & Sayuran & $\begin{array}{l}\text { Sistem campuran } \\
\text { (pala+gaharu+cengkeh+ka } \\
\text { kao+kopi+sayuran (tomat, } \\
\text { cabai,kentang, bawang)) }\end{array}$ & $\begin{array}{l}\text { Cengkeh, kopi, } \\
\text { pala }\end{array}$ \\
\hline Balang Pesoang & Tidak ada & & & $\begin{array}{l}\text { Sistem campuran } \\
\text { (cengkeh+lada+ } \\
\text { manggis+pala) } \\
\text { Sistem monokultur: karet }\end{array}$ & $\begin{array}{l}\text { Cengkeh, durian, } \\
\text { lada, manggis, } \\
\text { pala, duku, } \\
\text { kakao, karet }\end{array}$ \\
\hline \multicolumn{6}{|c|}{ Timber village group } \\
\hline Tana Toa & Tidak ada & & & $\begin{array}{l}\text { Sistem campuran } \\
\text { (karet+durian) }\end{array}$ & \\
\hline Tugondeng & 2011 & $\begin{array}{l}\text { Dinas } \\
\text { Pertanian }\end{array}$ & $\begin{array}{l}\text { Padi, jagung, } \\
\text { rehabilitasi } \\
\text { kakao }\end{array}$ & Tugondeng & 2011 \\
\hline
\end{tabular}




\section{Program kunjungan silang di Sulawesi Selatan}

Hanya petani di Balang Pesoang yang belum pernah mengalami kunjungan silang (Lampiran 4). Kunjungan silang biasanya diadakan oleh pemerintah setempat untuk para petani setidaknya sekali setahun. Dinas Pertanian, Dinas Kehutanan, dan Dinas Perkebunan adalah badan pemerintahan lokal yang mendukung kegiatan kunjungan silang di tiap kabupaten. Sayangnya, peserta yang menghadiri kunjungan silang ini dibatasi hingga 15 orang per desa dengan partisipasi perempuan bervariasi dari 0-50\%. Isu yang dipelajari selama kunjungan silang selama sepuluh tahun terakhir adalah: a) pengelolaan unggas; b) budi daya sayuran; c) produksi madu; dan d) budi daya kakao.

Diskusi kelompok terarah di tingkat desa menunjukkan para petani tertarik untuk mempelajari budi daya pohon buah, sayuran, karet, kakao, cengkeh, dan gaharu pada saat kunjungan ke lokasi lain, yang antara lain mencakup Malino, Loka-Bantaeng, Enrekang, Sidrap, Tana Toraja, Takalar, Sinjai Barat, Palopo, Bulukumba, Sinjai, Soppeng dan Kendari (Lampiran 5). Enrekang, Sidrap, dan Palopo adalah tiga lokasi paling menarik untuk para petani.

\section{Penyuluhan pemasaran di Sulawesi Selatan}

Sebagian petani sangat tergantung pada pedagang tertentu untuk menjual produknya karena petani seringkali berutang uang kepada para pedagang tersebut untuk kebutuhan sehari-hari. Hal ini terjadi terutama ketika musim berbuah cengkeh tidak jelas. Isu sensitif ini sepertinya menghalangi para petani untuk meminta isu pemasaran dicantumkan ke dalam layanan penyuluhan proyek AgFor. Namun, pembangunan infrastruktur di Sulawesi Selatan lebih maju daripada Sulawesi Tenggara, sehingga menyediakan kesempatan lebih baik bagi petani di Sulawesi Selatan untuk mengakses pasar. Permintaan intervensi AgFor untuk masalah pemasaran tidak memiliki perbedaan yang nyata antar kelompok desa.

\section{Preferensi antara laki-laki dengan perempuan untuk kebutuhan penyuluhan pertanian di Sulawesi Selatan}

Di semua desa di Sulawesi Selatan, tidak ada perbedaan antara laki-laki dan perempuan terkait dengan layanan penyuluhan proyek AgFor yang diharapkan. Namun, kelompok perempuan cenderung lebih tertarik pada tanaman berumur pendek (seperti sayuran dan komoditas lain yang bisa diproduksi kurang dari tiga tahun) dibandingkan tanaman berumur panjang (pohon kayu dan buah).

Pada kegiatan penyuluhan pertanian yang sudah dilakukan, kehadiran peserta perempuan biasanya memiliki rentang lebar dari 0-80\% dari total jumlah peserta penyuluhan tergantung pada tipe kegiatan penyuluhan. Hal ini karena perempuan jarang yang menjadi anggota kelompok petani dibandingkan laki-laki. Sebagian besar kelompok petani beranggotakan laki-laki, hal ini mungkin karena peran lakilaki yang lebih kuat sebagai pengambil keputusan di pengelolaan pertanian dibandingkan perempuan. Di semua desa yang dikunjungi, $100 \%$ responden setuju bahwa para laki-laki adalah pembuat keputusan dalam pengelolaan kebun.

Alokasi waktu dalam pengelolaan kebun dapat dijadikan aspek penting dalam penentuan kebutuhan laki-laki dan perempuan untuk mendapatkan layanan penyuluhan pertanian. Biasanya para laki-laki menghabiskan waktu lebih banyak dalam kegiatan pengelolaan kebun yang berhubungan dengan pembukaan lahan; penanaman; perawatan; dan panen, sehingga kebutuhan penyuluhan untuk peningkatan kapasitas dan keahlian para laki-laki dapat difokuskan pada keempat kegiatan tersebut. 
Di sisi lain, walaupun perempuan tidak terlalu berperan di dalam pembuatan keputusan pengelolaan kebun, perempuan berperan cukup penting terutama dalam perawatan pembibitan, pemanenan, dan proses pascapanen. Hal menarik lain adalah sekitar 75\% responden di Sulawesi Selatan setuju bahwa perempuan memiliki peran penting dalam pemasaran produk pertanian. Oleh karena itu, penyuluhan pertanian dapat difokuskan pada peningkatan kapasitas dan keahlian perempuan terutama untuk kegiatan yang terkait dengan: perawatan pembibitan; proses pemanenan dan pascapanen; dan pemasaran produk.

\section{Media komunikasi di Sulawesi Selatan}

Semua kelompok desa di Sulawesi Selatan berpendapat bahwa televisi merupakan media paling efektif untuk penyuluhan pertanian (Tabel 9). Namun, saat ini hanya ada sedikit program penyuluhan pertanian yang ditayangkan di televisi ,selain itu beberapa desa proyek tidak memiliki listrik. Ponsel dianggap sebagai alat paling efektif kedua oleh semua kelompok desa. Ponsel berpotensi untuk memberikan informasi mengenai harga produk pertanian. Hanya kelompok desa AF-Bantaeng yang menganggap CD/DVD sebagai media paling efektif. Radio, majalah, dan koran memiliki peringkat terendah sebagai media komunikasi yang efektif di Sulawesi Selatan.

Tabel 9. Peringkat efektivitas media komunikasi untuk penyuluhan pertanian di Sulawesi Selatan

\begin{tabular}{lllcll}
\hline \multirow{1}{*}{$\begin{array}{c}\text { Kelompok } \\
\text { desa }\end{array}$} & \multicolumn{5}{c}{ Peringkat media komunikasi yang efektif } \\
\cline { 2 - 5 } $\begin{array}{l}\text { Lahan } \\
\text { terdegradsi }\end{array}$ & Televisi & Ponsel, Koran & $\mathbf{3}$ & $\mathbf{4}$ & $\mathbf{5}$ \\
\hline AF-Bantaeng & Televisi & CD/DVD & Ponsel & Radio, \\
majalah & Majalah & Radio \\
\hline AF-Bulukumba & Televisi & Ponsel & Radio & Koran & CD/DVD \\
\hline Kayu & Televisi & Ponsel, radio & & Koran & CD/DVD \\
\hline
\end{tabular}

Catatan: 1 = paling efektif.

\section{Penyuluhan agroforestri pada tingkat masyarakat di Sulawesi Tenggara}

\section{Penetapan prioritas jenis tanaman di Sulawesi Tenggara}

Berdasarkan kondisi pasar dan kondisi terkini, tanaman prioritas berbeda di antara kelompok desa di Sulawesi Tenggara (Tabel 10). Perbedaan tampak kontras di kelompok desa transmigran baru dibandingkan dengan kelompok desa lain. Di kelompok desa transmigran baru, tanaman berumur pendek dijadikan prioritas sebagai sumber penghidupan karena para petani belum memiliki tabungan uang dan tanaman pohon mereka baru ditanam dan belum produktif. Di sisi lain, kelompok desa transmigran, yang sudah ada di area itu selama lebih dari 20 tahun, tidak bergantung hanya pada tanaman berumur pendek, tapi juga menjadikan kakao, lada, durian, dan rambutan sebagai sumber mata pencaharian utama. Kelompok desa transmigran baru dan kelompok desa transmigran juga memanen HHNK seperti madu, kayu bakar, dan gula aren (dari Arenga pinnata) untuk menambah penghasilan. 
Desa lokal dan kelompok desa campuran memilih kakao, lada, dan durian sebagai tanaman prioritas mereka. Kelompok desa campuran juga memilih cengkeh sebagai tanaman prioritas karena budi daya cengkeh sudah berhasil dilakukan di Sulawesi Selatan. Di kelompok desa campuran, para petani pendatang dari Sulawesi Selatan berbagi pengetahuan mengenai budi daya cengkeh dengan rekan mereka dari suku lainnya. Kelompok desa campuran tidak menjadikan HHNK sebagai sumber mata pencaharian, sementara kelompok desa lokal masih menjadikan HHNK sebagai sumber penghasilan.

Berdasarkan tanaman potensial atau yang diharapkan untuk intervensi proyek AgFor, kelompok desa lokal dan kelompok desa transmigran baru menganggap karet penting. sementara untuk kelompok desa campuran dan kelompok desa transmigran, durian menjadi pilihan utama. Durian juga merupakan pilihan tanaman potensial kedua untuk kelompok desa lokal dan kelompok transmigran baru. Kakao dan lada adalah pilihan kedua dari semua kelompok desa kecuali kelompok desa transmigran baru yang memilih kelapa, cengkeh, tanaman berumur pendek (sayuran, cabai, tomat, kacang-kacangan), jagung, jati, dan durian sebagai prioritas kedua dan ketiga. Yang menarik adalah nilam yang tidak dipilih sebagai jenis tanaman potensial karena harga daun nilam yang rendah, sekalipun nilam pernah berkontribusi terhadap mata pencaharian lokal.

Tabel 10. Tanaman prioritas di Sulawesi Tenggara oleh kelompok desa berdasarkan intervensi yang diharapkan oleh AgFor (E), kondisi pasar terkini (M), dan prioritas terkini dalam mata pencaharian setempat (C)

\begin{tabular}{|c|c|c|c|c|c|c|c|c|c|c|c|c|}
\hline \multirow{3}{*}{ Tanaman } & \multicolumn{12}{|c|}{ Prioritas tanaman kelompok desa } \\
\hline & \multicolumn{3}{|c|}{ Lokal } & \multicolumn{3}{|c|}{ Campuran } & \multicolumn{3}{|c|}{ Transmigran } & \multicolumn{3}{|c|}{ Transmigran baru } \\
\hline & $\mathbf{E}$ & $\mathbf{M}$ & C & E & $\mathbf{M}$ & C & $\mathbf{E}$ & $\mathbf{M}$ & C & E & $\mathbf{M}$ & C \\
\hline Karet & 1 & & & 2 & & & & & & 1 & & \\
\hline Kakao & 2 & 1 & 1 & 2 & 1 & 1 & 3 & 1 & 2 & & 3 & 2 \\
\hline Kopi & & & & & & & & & & & 8 & 2 \\
\hline Kelapa & & 3 & 6 & 9 & 10 & & & 1 & 2 & 2 & & 8 \\
\hline Lada & 3 & 1 & 2 & 4 & 3 & 1 & 2 & 1 & 2 & & 8 & \\
\hline Cengkeh & 5 & & & 5 & & 6 & & & & 3 & & 8 \\
\hline Nilam & & 4 & 6 & & 7 & 8 & & 5 & 7 & & & \\
\hline Pala & & & & 5 & & & & & & & & \\
\hline Kemiri & & 7 & & & & & & & & & & \\
\hline $\begin{array}{l}\text { Tanaman umur } \\
\text { pendek (sayuran, } \\
\text { cabai, tomat, } \\
\text { kacang- } \\
\text { kacangan) }\end{array}$ & 7 & 4 & 4 & 9 & 7 & 5 & & 1 & 1 & 3 & 1 & 1 \\
\hline Sagu & & & 6 & & & & & & 7 & & & 8 \\
\hline Jagung & 7 & & & & & & & & 7 & 3 & & \\
\hline $\begin{array}{l}\text { HHNK (madu, } \\
\text { kayu bakar, aren) }\end{array}$ & & 7 & & & & & & 5 & & & 2 & \\
\hline Kayu & & & & & & & & & & & & \\
\hline Kayu & 7 & & & & 1 & & & & & & 8 & \\
\hline Jati & 5 & & 6 & 8 & 10 & 6 & & 5 & 7 & 3 & 8 & 8 \\
\hline Buah & & & & & & & & & & & & \\
\hline Durian & 3 & 7 & 2 & 1 & 3 & 1 & 1 & 5 & 2 & 3 & 3 & 2 \\
\hline
\end{tabular}




\begin{tabular}{|c|c|c|c|c|c|c|c|c|c|c|c|c|}
\hline \multirow{3}{*}{ Tanaman } & \multicolumn{12}{|c|}{ Prioritas tanaman kelompok desa } \\
\hline & \multicolumn{3}{|c|}{ Lokal } & \multicolumn{3}{|c|}{ Campuran } & \multicolumn{3}{|c|}{ Transmigran } & \multicolumn{3}{|c|}{ Transmigran baru } \\
\hline & $\mathbf{E}$ & M & C & $\mathbf{E}$ & $\mathbf{M}$ & C & $\mathbf{E}$ & $\mathbf{M}$ & C & $\mathbf{E}$ & $\mathbf{M}$ & C \\
\hline Rambutan & & 7 & 4 & 5 & 3 & 4 & 3 & 5 & 2 & & 3 & 2 \\
\hline Pisang & & & & & 7 & 8 & & & & & 3 & 2 \\
\hline Jeruk & & & & & & & & & & & 3 & 2 \\
\hline Duku & & 4 & 6 & & 6 & 8 & & 5 & 7 & & & \\
\hline Nangka & & & & & & & & & 7 & & & \\
\hline Mangga & & & & & & & & & 7 & & & \\
\hline
\end{tabular}

Catatan: 1 = prioritas tertinggi. $\mathrm{E}=$ ekspektasi, $\mathrm{C}=$ sekarang, $\mathrm{M}=$ pasar, $\mathrm{HHNK}=$ hasil hutan nonkayu

Secara ringkas, durian adalah pilihan paling populer karena buah ini memiliki harga tinggi dan ada pilihan untuk menjual kayunya ketika produksi buah durian menurun. Karet ada di peringkat kedua, tetapi sekarang ini, hanya ada beberapa petani yang menanam karet karena kurangnya akses ke bahan tanam karet dan ketiadaan pasar lokal untuk karet di Sulawesi Tenggara. Untuk itu, eksplorasi pasar karet potensial dianggap sangat penting jika tanaman ini akan dimasukkan sebagai jenis prioritas utama di dalam intervensi proyek AgFor. Kakao dan lada, dua tanaman paling penting untuk mata pencaharian lokal juga dipilih sebagai jenis tanaman prospektif untuk intervensi proyek, terutama berkaitan dengan penanggulangan hama dan penyakit yang saat ini menyerang kedua jenis tanaman ini. Cengkeh dan jati dipilih untuk intervensi AgFor karena para petani tidak memiliki akses ke bahan tanam atau informasi mengenai budi daya tanaman-tanaman ini. Pisang dan tanaman berumur pendek lain dipilih karena durasi waktu panen yang sedikit, sekalipun aspek penanggulangan hama dan penyakit serta pemasaran masih membutuhkan perbaikan lebih jauh. Kurangnya akses ke bahan tanam yang berkualitas baik, kurangnya inovasi penanggulangan hama dan tanaman, dan kurangnya inovasi dalam strategi pemasaran untuk jenis tanaman prospektif adalah alasan-alasan utama para petani memilih tanaman yang disebutkan di atas untuk intervensi proyek.

Namun, di Sulawesi Tenggara, selama bertahun-tahun pemerintah telah mempertahankan program distribusi bibit untuk meningkatkan akses petani ke bahan tanam. Badan pemerintahan yang mendistribusikan bibit terutama adalah Dinas Pertanian, Dinas Perkebunan, dan Dinas Kehutanan. Bibit didistribusikan berdasarkan permintaan/proposal yang dibuat oleh kelompok petani (Lampiran 6). Dinas-dinas biasanya akan mendistribusikan bibit jenis tanaman yang tersedia dari jenis tanaman baru atau yang sudah dikenal baik. Selain itu, dinas-dinas terkadang sulit mendapatkan bibit karena kurangnya informasi mengenai tempat mendapatkan bahan tanam yang baik, juga kurang tersedianya tanaman induk berkualitas baik dari jenis tanaman yang diajukan para petani. Maka, proyek AgFor diharapkan akan dapat membantu peningkatan akses petani dan pemerintah setempat pada bahan tanam berkualitas baik.

\section{Layanan penyuluhan di Sulawesi Tenggara}

Selama lima tahun terakhir kebanyakan petani sudah mendapatkan pelatihan (Lampiran 7) dan kegiatan di kelas (Lampiran 8) mengenai topik pertanian seperti budi daya sayuran, enten samping kakao, dan pembuatan kompos. Para petani di Wonua Hoa (yang merupakan pendatang dari Sulawesi Selatan) belum pernah mendapatkan pelatihan apa pun dari organisasi mana pun, mungkin karena 
akses jalan yang buruk dari jalan utama menuju ke area pemukiman. Untuk layanan penyuluhan sebelumnya, sekitar 0-30\% dari total peserta adalah perempuan.

Diskusi kelompok terarah di tingkat desa tidak menunjukkan perbedaan nyata antar kelompok desa terhadap topik utama yang diharapkan diberikan pada layanan penyuluhan di kelas oleh proyek AgFor. Teknik penanaman dan perawatan tanaman mendominasi permintaan topik penyuluhan diikuti oleh penanggulangan hama dan penyakit. Identifikasi varietas tanaman adalah topik pilihan selanjutnya, diikuti dengan pengelolaan ternak. Walaupun tidak ada perbedaan nyata terhadap pilihan topik penyuluhan di kelas antara kelompok desa, tiap desa memiliki prioritas tanaman yang berbeda pada masing-masing topik penyuluhan, contohnya, terkait dengan kegiatan di kelas mengenai teknik budi daya, para petani di Lawonua (desa campuran) berfokus pada karet, sementara di Wonua Hoa mereka berfokus pada kakao dan padi (Tabel 11).

Tabel 11. Topik potensial untuk kegiatan penyuluhan di kelas pada proyek AgFor di Sulawesi Tenggara

\begin{tabular}{|c|c|c|c|c|}
\hline \multirow[b]{2}{*}{ Desa } & \multicolumn{4}{|c|}{ Topik } \\
\hline & $\begin{array}{c}\text { Teknik penanaman } \\
\text { dan perawatan } \\
\text { tanaman }\end{array}$ & $\begin{array}{c}\text { Penanggulangan hama } \\
\text { dan penyakit }\end{array}$ & $\begin{array}{l}\text { Identifikasi varietas } \\
\text { tanaman }\end{array}$ & $\begin{array}{c}\text { Pengelolaan } \\
\text { ternak }\end{array}$ \\
\hline \multicolumn{5}{|c|}{ Kelompok desa lokal } \\
\hline Ambondiaa & Karet, kakao, gaharu & $\begin{array}{l}\text { Kakao, durian, rambutan, } \\
\text { kopi, nilam }\end{array}$ & $\begin{array}{l}\text { Semua tanaman } \\
\text { yang cocok ditanam } \\
\text { di Ambondiaa }\end{array}$ & Sapi dan unggas \\
\hline Lamunde & Kakao, padi, lada & Semua tanaman di desa & & Sapi dan unggas \\
\hline Simbune & Kakao, lada & Lada & & \\
\hline Taosu & Karet, pala & Semua tanaman di desa & Kakao & \\
\hline \multicolumn{5}{|c|}{ Kelompok desa campuran } \\
\hline Anggawo & $\begin{array}{l}\text { Karet, durian (musim } \\
\text { berbuah) }\end{array}$ & & & \\
\hline Lawonua & Karet & & & \\
\hline $\begin{array}{l}\text { Wonua Hoa } \\
\text { pendatang }\end{array}$ & $\begin{array}{l}\text { Karet, jahe merah, } \\
\text { cabai }\end{array}$ & & Kakao & \\
\hline $\begin{array}{l}\text { Wonua Hoa } \\
\text { lokal }\end{array}$ & $\begin{array}{l}\text { Kakao dan padi (cara } \\
\text { memanfaatkan sawah } \\
\text { selama masa puso) }\end{array}$ & Kakao & Kakao & \\
\hline \multicolumn{5}{|c|}{ Kelompok desa transmigran baru } \\
\hline Tasahea & $\begin{array}{l}\text { Lada, kakao, kelapa, } \\
\text { cengkeh }\end{array}$ & $\begin{array}{l}\text { Lada (cara memilih } \\
\text { varietas lada unggul) }\end{array}$ & $\begin{array}{l}\text { Durian, kakao dan } \\
\text { lada }\end{array}$ & Babi dan sapi \\
\hline \multicolumn{5}{|c|}{ Kelompok desa transmigran baru } \\
\hline $\begin{array}{l}\text { UPT Asinua } \\
\text { Jaya } \\
\text { (Lasao) }\end{array}$ & Cengkeh, durian, karet & Semua tanaman di desa & & \\
\hline
\end{tabular}


Dalam konteks pelatihan, masing-masing kelompok desa memiliki prioritas yang berbeda-beda (Tabel 12). Di kelompok desa lokal, $100 \%$ dari semua desa memilih topik perbanyakan vegetatif, $75 \%$ memilih pupuk organik, dan $25 \%$ memilih penanggulangan hama dan penyakit, pengelolaan kakao pascapanen, dan penilaian kesesuaian lahan. Di kelompok desa campuran, 75\% dari desa memilih peremajaan kakao, 50\% memilih perbanyakan vegetatif, dan penanggulangan hama dan penyakit, dan $25 \%$ memilih agroforestri karet dan pembangkit listrik tenaga mikro hidro (microhydropower). Para petani di kelompok desa transmigran memilih penanggulangan hama dan penyakit. Kelompok desa transmigran baru memilih perbanyakan vegetatif. Secara umum, perbanyakan vegetatif adalah topik pelatihan yang paling diminati, diikuti dengan penanggulangan hama dan penyakit, peremajaan kakao, dan pupuk organik. 
Tabel 12. Tipe pelatihan yang diharapkan di tingkat desa melalui layanan penyuluhan AgFor di Sulawesi Tenggara

\begin{tabular}{|c|c|c|c|c|c|c|c|c|}
\hline \multirow[b]{2}{*}{ Desa } & \multicolumn{8}{|c|}{ Topik-topik pelatihan yang diharapkan } \\
\hline & $\begin{array}{l}\text { Perbanyakan } \\
\text { vegetatif }\end{array}$ & $\begin{array}{l}\text { Peremajaan } \\
\text { kakao }\end{array}$ & $\begin{array}{l}\text { Penanggulangan } \\
\text { hama dan } \\
\text { penyakit }\end{array}$ & $\begin{array}{c}\text { Pupuk } \\
\text { organik }\end{array}$ & $\begin{array}{l}\text { Agro- } \\
\text { forestri } \\
\text { karet }\end{array}$ & $\begin{array}{l}\text { Pembangkit } \\
\text { listrik mikro } \\
\text { hidro }\end{array}$ & $\begin{array}{c}\text { Pascapanen } \\
\text { kakao }\end{array}$ & $\begin{array}{l}\text { Penilaian } \\
\text { kesesuaian } \\
\text { lahan }\end{array}$ \\
\hline \multicolumn{9}{|l|}{ Kelompok desa lokal } \\
\hline Persentase total & 100 & 0 & 25 & 75 & 0 & 0 & 25 & 25 \\
\hline Ambondiaa & v & & & & & & & \\
\hline Lamunde & $\mathrm{v}$ & & $\mathrm{v}$ & $\mathrm{v}$ & & & & $\mathrm{v}$ \\
\hline Simbune & v & & & $v$ & & & v & \\
\hline Taosu & $\mathrm{v}$ & & & $\mathrm{v}$ & & & & \\
\hline \multicolumn{9}{|l|}{ Kelompok desa campuran } \\
\hline Persentase total & 50 & 75 & 50 & 0 & 25 & 25 & 0 & 0 \\
\hline Anggawo & & $v$ & $\mathrm{v}$ & & & $\mathrm{v}$ & & \\
\hline Lawonua & $\mathrm{v}$ & v & & & $\mathrm{V}$ & & & \\
\hline Wonua Hoa pendatang & $\mathrm{v}$ & $\mathrm{v}$ & & & & & & \\
\hline Wonua Hoa lokal & & & $\mathrm{v}$ & & & & & \\
\hline \multicolumn{9}{|c|}{ Kelompok desa transmigran } \\
\hline Persentase total & 0 & 0 & 100 & 0 & 0 & 0 & 0 & 0 \\
\hline Tasahea & & & $\mathrm{v}$ & & & & & \\
\hline \multicolumn{9}{|c|}{ Kelompok desa transmigran baru } \\
\hline Persentase total & 100 & 0 & 0 & 0 & 0 & 0 & 0 & 0 \\
\hline UPT Asinua Jaya ( Lasao) & $\mathrm{v}$ & & & & & & & \\
\hline
\end{tabular}




\section{Lahan percontohan di Sulawesi Tenggara}

Di kebanyakan desa, beberapa lahan percontohan sudah pernah dibangun oleh pemerintah daerah setempat (Tabel 13). Akan tetapi hal tersebut tidak terjadi di semua kelompok desa. Para petani kelompok desa campuran di Anggawo dan Wonua Hoa tidak dapat menjawab ketika ditanya soal harapan mereka mengenai rancangan lahan percobaan di dalam proyek AgFor. Sementara itu, kelompok desa transmigran dan transmigran baru lebih berpengalaman dengan lahan percontohan karena adanya program pemerintah yang intensif pada beberapa tahun pertama ketika para petani ditempatkan di lokasi transmigrasi.

Tabel 13. Lahan percontohan petani yang pernah ada dan yang diharapkan di desa-desa proyek AgFor Sulawesi Tenggara

\begin{tabular}{|c|c|c|c|c|c|}
\hline \multirow[b]{2}{*}{ Desa } & \multicolumn{3}{|c|}{ Lahan percontohan yang pernah ada di desa } & \multicolumn{2}{|c|}{$\begin{array}{l}\text { Lahan percontohan yang diharapkan di } \\
\text { proyek AgFor }\end{array}$} \\
\hline & Tahun & Badan & $\begin{array}{l}\text { Lahan } \\
\text { percontohan }\end{array}$ & $\begin{array}{l}\text { Lahan percontohan } \\
\text { kebun }\end{array}$ & $\begin{array}{l}\text { Lahan } \\
\text { percontohan } \\
\text { pembibitan }\end{array}$ \\
\hline \multicolumn{6}{|c|}{ Kelompok desa lokal } \\
\hline Ambondiaa & 2011 & Dinas Pertanian & $\begin{array}{l}\text { Padi untuk } \\
\text { lahan kering }\end{array}$ & $\begin{array}{l}\text { Sistem campuran } \\
\text { (karet+ kakao+ durian) }\end{array}$ & Karet \\
\hline Lamunde & & & Sawah padi & $\begin{array}{l}\text { Sistem campuran } \\
\text { (kakao+ } \\
\text { durian+lada+karet+ } \\
\text { cengkeh) }\end{array}$ & \\
\hline Simbune & & Universitas & $\begin{array}{l}\text { Enten } \\
\text { samping }\end{array}$ & $\begin{array}{l}\text { Sistem campuran } \\
\text { (kakao+lada) }\end{array}$ & \\
\hline Taosu & Tidak ada & & & $\begin{array}{l}\text { Sistem campuran } \\
\text { (karet+pala) }\end{array}$ & Karet dan pala \\
\hline \multicolumn{6}{|c|}{ Kelompok desa campuran } \\
\hline Anggawo & Tidak ada & & & & \\
\hline Lawonua & Tidak ada & & & $\begin{array}{l}\text { Sistem campuran } \\
\text { (karet+ durian+ } \\
\text { lada+buah) }\end{array}$ & \\
\hline $\begin{array}{l}\text { Wonua Hoa- } \\
\text { lokal }\end{array}$ & Tidak ada & & & $\begin{array}{l}\text { Sistem campuran } \\
\text { tanaman berumur } \\
\text { pendek (dipanen dalam } \\
13 \text { tahun) }\end{array}$ & Durian \\
\hline $\begin{array}{l}\text { Wonua Hoa- } \\
\text { pendatang }\end{array}$ & Tidak ada & & & & Buah, durian, karet \\
\hline \multicolumn{6}{|c|}{ Kelompok desa transmigran } \\
\hline Tasahea & 1986 & & $\begin{array}{l}\text { Monokultur } \\
\text { jeruk }\end{array}$ & Sistem monokultur: lada & \\
\hline \multicolumn{6}{|c|}{ Kelompok desa transmigran baru } \\
\hline $\begin{array}{l}\text { UPTAsinua } \\
\text { Jaya } \\
\text { (Lasao) }\end{array}$ & & $\begin{array}{l}\text { Dinas Pertanian, } \\
\text { Dinas Tenaga } \\
\text { Kerja dan Trans- } \\
\text { migrasi }\end{array}$ & $\begin{array}{l}\text { Sayuran } \\
\text { (tomat, cabai) }\end{array}$ & $\begin{array}{l}\text { Sistem campuran } \\
\text { (cengkeh+ durian+ } \\
\text { karet+jati+ kelapa) }\end{array}$ & $\begin{array}{l}\text { Cengkeh, karet, } \\
\text { durian }\end{array}$ \\
\hline
\end{tabular}


Rancangan untuk lahan percontohan yang diharapkan di proyek AgFor bervariasi antara kelompok desa tergantung pada mata pencaharian utama di daerah tersebut dan jumlah lahan yang tersedia. Kebanyakan petani mengharapkan lahan percontohan difokuskan pada topik cara menanam jenis tanaman yang berbeda pada lahan percontohan yang sama, kecuali para petani di Tasahea yang ingin fokus pada perbaikan perkebunan lada dalam sistem monokultur.

\section{Program kunjungan silang di Sulawesi Tenggara}

Lima dari sembilan desa proyek AgFor di Sulawesi Tenggara belum pernah mengalami kunjungan silang (Lampiran 9). Sebelumnya, kegiatan kunjungan silang sebagian besar diadakan oleh Dinas Pertanian dan Kehutanan di tiap kabupaten. Kedua dinas tersebut mengundang petani untuk mengadakan kunjungan silang setidaknya setahun sekali. Namun, karena keterbatasan dana, kehadiran petani dibatasi hingga lima orang per desa (peserta perempuan bervariasi antara 0-30\%). Frekuensi kunjungan silang juga tidak pasti. Topik-topik yang dipelajari selama kunjungan silang yang diadakan oleh pemerintah dalam sepuluh tahun terakhir adalah budi daya kakao, budi daya vanili, dan pengelolaan ternak sapi.

Diskusi kelompok terarah menunjukkan bahwa para petani tertarik untuk belajar lebih banyak mengenai budi daya kakao, karet, durian, cengkeh, dan lada di Bulukumba, Sinjai, Palopo, Lambandia, dan Maros. Lambandia dan Bulukumba dianggap sebagai lokasi paling menarik untuk dikunjungi (Lampiran 10).

\section{Penyuluhan pemasaran di Sulawesi Tenggara}

Isu pemasaran kebanyakan terkait dengan keterbatasan akses ke pasar. Ketergantungan tinggi pada pedagang tertentu (yang terjadi di Sulawesi Selatan) tidak menjadi isu pemasaran utama di Sulawesi Tenggara. Akses jalan yang buruk adalah tantangan utama dalam pemasaran produk pertanian. Berdasarkan diskusi kelompok terarah, Desa Tasahea dan Simbune secara spesifik meminta proyek AgFor untuk memfasilitasi pembentukan kelompok pemasaran (kemungkinan melalui kerja sama) seperti yang sudah terbentuk di Desa Ladongi, Kecamatan Lambandia, dan di Kabupaten Kolaka melalui Lembaga Ekonomi Masyarakat, yang sudah membantu masyarakat untuk memasarkan benih kakao secara kolektif. Para petani di daerah transmigrasi baru seperti Desa UPT Asinua (Lasao), yang berlokasi di daerah terpencil di Kabupaten Konawe, meminta proyek AgFor untuk membantu mereka memasarkan pisang dan jika mungkin membantu para petani berkomunikasi dengan pemerintah setempat untuk memperbaiki jalan di daerah itu. Tidak ada perbedaan nyata di antara kelompok desa di Sulawesi Tenggara dalam hal permintaan untuk intervensi penyuluhan pemasaran melalui proyek AgFor.

\section{Preferensi antara laki-laki dan perempuan untuk kebutuhan penyuluhan pertanian di Sulawesi Tenggara}

Tidak ada perbedaan nyata dalam pilihan laki-laki maupun perempuan terhadap kebutuhan layanan penyuluhan di semua kelompok desa di Sulawesi Tenggara. Namun, para perempuan cenderung mengharapkan bantuan terkait dengan penanganan pascapanen, perbanyakan vegetatif, dan penanggulangan hama dan penyakit. Sebagai perbandingan, para laki-laki memilih topik tentang pengelolaan lahan dan pembibitan. Para perempuan lebih memprioritaskan tanaman berumur pendek 
(seperti sayuran), sedangkan para laki-laki lebih memprioritaskan tanaman berumur panjang (pohon kayu dan buah).

Dalam kegiatan penyuluhan pertanian sebelumnya, peserta perempuan berkisar antara 10-50\% dari keseluruhan peserta. Kebanyakan anggota kelompok tani di Sulawesi Tenggara adalah laki-laki. Perempuan lebih aktif di kegiatan pengelolaan kebun pekarangan.

Semua desa yang disurvei sepakat bahwa laki-laki adalah pembuat keputusan utama dalam pengelolaan kebun. Laki-laki memberikan alokasi waktu lebih banyak dalam pembukaan lahan yang meliputi proses penanaman, perawatan dan pemanenan, sehingga peningkatan kapasitas dan keahlian petani laki-laki dapat diprioritaskan pada topik-topik kegiatan tersebut. Sedangkan untuk perempuan, pengembangan kapasitas dapat dilakukan pada topik tentang perawatan pembibitan, pemanenan atau pengelolaan pascapanen dan pemasaran produk.

\section{Media komunikasi di Sulawesi Tenggara}

Pemeringkatan efektivitas media berbeda di antara kelompok desa di Sulawesi Tenggara (Tabel 14). Kelompok desa lokal cenderung memilih televisi sebagai media paling efektif untuk penyuluhan pertanian, sementara kelompok desa campuran memilih majalah. Kelompok desa transmigran memilih DVD sementara kelompok desa transmigran baru memilih radio. Di kelompok desa transmigran baru, hanya ada dua tipe media yang dipilih karena bentuk lain tidak tersedia di area tersebut mengingat lokasinya yang terpencil dan ketidaktersediaan listrik. Namun, ponsel dan radio umum dimiliki di semua desa, sehingga kedua media ini memiliki potensi lebih besar sebagai media komunikasi yang efektif untuk penyuluhan pertanian di Sulawesi Tenggara.

Tabel 14. Peringkat efektivitas media komunikasi untuk penyuluhan pertanian di Sulawesi Tenggara

\begin{tabular}{|c|c|c|c|c|c|}
\hline \multirow{2}{*}{ Kelompok desa } & \multicolumn{5}{|c|}{ Peringkat media komunikasi yang efektif } \\
\hline & 1 & 2 & 3 & 4 & 5 \\
\hline Lokal & Televisi & Radio & Ponsel & Koran & CD/DVD \\
\hline Campuran & Majalah & Radio & Televisi & Ponsel & Koran \\
\hline Transmigran & CD/DVD & Ponsel, televisi & & Radio & Koran \\
\hline Transmigran baru & Radio & Ponsel & & & \\
\hline
\end{tabular}

Note: 1 = paling efektif.

\section{Kesimpulan}

Kebutuhan penyuluhan agroforestri di tingkat masyarakat di lokasi proyek AgFor baik di Sulawesi Selatan maupun di Sulawesi Tenggara dianalisis dengan meninjau isu yang relevan dengan sektor pertanian, kehutanan, dan perkebunan, dengan fokus yang lebih kuat pada sektor pertanian yang memiliki agenda penyuluhan yang lebih luas. Saat ini di Indonesia, penyuluhan agroforestri masih tergabung di dalam satu organisasi dengan penyuluhan pertanian. Survei ini menjelaskan kondisi penyuluhan pertanian saat ini dan potensinya di masa mendatang. 
Secara umum, di kedua provinsi, penyuluh pertanian memiliki peran penting dalam meningkatkan akses informasi dan teknologi para petani, selain juga menerjemahkan hasil penelitian menjadi kondisi nyata di lapangan. Maka, koordinasi yang baik antara penyuluh dan badan penelitian diharapkan akan meningkatkan penyebaran hasil penelitian baru yang dapat meningkatkan produktivitas lahan petani. Akan tetapi hingga saat ini kenyataannya, koordinasi antara institusi sekarang masih lemah. Terlebih, badan penyuluhan pemerintah sekarang ini masih berjuang untuk mengatasi tantangan utama dalam peningkatan layanan, di antaranya adalah:

- Kurangnya penyuluh. Pendekatan petani ke petani dengan menggunakan petani andalan sebagai penyuluh direkomendasikan untuk mengatasi masalah ini; pendekatan petani ke petani diakui memiliki potensi untuk melanjutkan pertukaran informasi dan penyebaran inovasi di tingkat masyarakat.

- Kurangnya kapasitas teknis dan motivasi penyuluh dalam memfasilitasi terbentuknya alternatif solusi dari persoalan yang dihadapi petani. Pemerintah sudah mencoba meningkatkan kapasitas teknis penyuluh melalui pelatihan. Motivasi penyuluh dapat ditingkatkan melalui skema penghargaan bagi penyuluh berprestasi.

- Kendala seperti ketidaktersediaan kendaraan untuk kunjungan silang dan kurangnya fasilitas penelitian untuk menguji dan membuat teknologi baru untuk memperbaiki produktivitas tanaman.

Di tingkat masyarakat, di kedua provinsi, ragam isu penyuluhan pertanian dapat diakibatkan oleh adanya perbedaan kondisi sosioekonomi seperti tingkat pendidikan dan pendapatan, kesukuan dan status infrastruktur. Sebagai contoh, ketidaksesuaian sosioekonomi dan biofisik dapat memunculkan prioritas tanaman masyarakat yang berbeda. Selain itu, kondisi infrastruktur memengaruhi potensi pemasaran dan akses petani pada informasi.

Di Sulawesi Selatan, untuk desa-desa di daerah dataran tinggi seperti kelompok desa berlahan terdegradasi, kelompok desa AF-Bantaeng dan kelompok desa AF-Bulukumba, cengkeh adalah pohon yang paling penting, sementara di dataran rendah (kelompok desa kayu), kelapa menjadi jenis pohon yang paling penting. Selain jenis tanaman pohon, tanaman berumur pendek (sayur, kacang-kacangan, labu siam, singkong, kacang, cabai, kubis, wortel) juga penting sebagai sumber mata pencaharian lokal di semua kelompok desa. Untuk intervensi proyek AgFor di Sulawesi Selatan, durian termasuk ke dalam jenis tanaman yang penting.

Sebagai perbandingan, di Sulawesi Tenggara, kakao adalah tanaman dengan prioritas tertinggi karena kakao telah berkontribusi dalammemperbaiki mata pencaharian masyarakat setempat selama bertahun-tahun, kecuali di daerah yang baru dibuka (kelompok desa transmigran baru), yang bergantung pada tanaman berumur pendek dan HHNK. Sama halnya dengan kondisi di Sulawesi Selatan, durian juga menjadi tanaman dengan permintaan tertinggi untuk dijadikan tanaman prioritas dalam proyek AgFor di Sulawesi Tenggara. Hal tersebut terutama karena varietas durian unggul memiliki harga yang cukup baik, seperti durian monthong atau durian otong.

Kurangnya akses informasi dan teknologi terbaru untuk memperbaiki produktivitas lahan biasanya menjadi salah satu motivasi petani untuk berpartisipasi dalam kegiatan penyuluhan. Pada lokasi AgFor, perbanyakan vegetatif merupakan topik pelatihan yang paling diminati oleh para petani di kedua provinsi (Tabel 15), diikuti dengan penanganan hama dan penyakit, dan produksi pupuk 
organik. Selain tanaman, para petani juga tertarik mempelajari lebih banyak soal pengelolaan ternak, karena ternak menjadi salah satu mata pencaharian di kedua provinsi.

Tabel 15. Topik prioritas untuk pelatihan proyek AgFor yang diminta oleh para petani di Sulawesi Selatan dan Tenggara

\begin{tabular}{lcc}
\hline \multirow{2}{*}{ Topik untuk pelatihan } & \multicolumn{2}{c}{ Jumlah desa per provinsi } \\
\cline { 2 - 3 } & $\begin{array}{c}\text { Sulawesi Selatan } \\
\text { (n total = 8 desa) }\end{array}$ & $\begin{array}{c}\text { Sulawesi Tenggara } \\
\text { (n total = 10 desa) }\end{array}$ \\
\hline Perbanyakan tanaman secara vegetatif & 7 & 7 \\
\hline Penanggulangan hama dan penyakit & 5 & 4 \\
\hline Pupuk organik & 5 & 3 \\
\hline Pengaturan jarak tanaman & 4 & 0 \\
\hline Produksi madu & 3 & 0 \\
\hline Peremajaan kebun kakao & 2 & 3 \\
\hline Budi daya karet & 1 & 1 \\
\hline
\end{tabular}

Selain pelatihan dan kegiatan di kelas, penyuluhan bisa dilakukan dengan membangun lahan percontohan, dengan harapan ada peningkatan pengetahuan dan keahlian para petani dalam perbaikan pengelolaan kebun dan pohon. Pada survei ini, lahan percontohan berpotensi untuk dibangun dengan topik utama perbaikan pengelolaan lahan. Tanaman yang akan ditanam di masing-masing lahan percontohan akan bervariasi antar desa. Di kedua provinsi, para petani masih belum terbiasa dengan konsep lahan percontohan karena sebelumnya ini bukan kegiatan yang umum dilakukan. Maka, di dalam intervensi proyek AgFor, penting untuk mengkonfirmasi ulang rancangan lahan percontohan dengan petani sebelum membangunnya.

Permintaan penyuluhan pertanian berdasarkan perbedaan jenis kelamin ternyata tidak terlalu berbeda antara kedua provinsi. Pada kegiatan penyuluhan pertanian yang pernah dilakukan, partisipasi kehadiran perempuan berkisar dari 0-80\%, tergantung pada tipe kegiatan penyuluhannya. Terkait dengan pemerataan kesempatan penyuluhan untuk laki-laki dan perempuan, kebutuhan penyuluhan pertanian dapat diidentifikasi melalui alokasi waktu untuk pengelolaan lahan pada masing-masing jenis kelamin. Laki-laki biasanya lebih banyak memberikan alokasi waktu untuk kegiatan i) pembukaan lahan; ii) penanaman; iii) perawatan; dan iv) pemanenan. Maka, keempat topik tersebut dapat dijadikan prioritas penyuluhan bagi laki-laki. Sementara, dalam pengelolaan lahan perempuan biasanya lebih banyak berperan dalam perawatan lahan, panen, pengelolaan pascapanen, dan pemasaran produk, sehingga kapasitas dan keahlian para perempuan ini dapat ditingkatkan berdasarkan topik-topik tersebut.

Untuk mencapai dampak yang lebih luas dan lebih berkelanjutan, media komunikasi dapat digunakan. Namun, hingga saat ini penggunaan media komunikasi masih belum optimal. Di Sulawesi Tenggara, menurut prioritas para petani, bentuk media komunikasi yang optimal bervariasi antara kelompok desa: kelompok desa berpenduduk lokal menempatkan televisi di peringkat tertinggi, sementara kelompok desa campuran memilih majalah, dan desa transmigran memilih CD/DVD, sedangkan kelompok desa transmigran baru menganggap radio sebagai media komunikasi yang paling efektif. Sementara itu, di Sulawesi Selatan, semua desa menganggap televisi sebagai media komunikasi 
paling efektif untuk penyuluhan pertanian. Namun, sekarang ini frekuensi program penyuluhan pertanian yang ditayangkan di televisi menurun. Maka, CD atau DVD bisa menjadi alternatif potensial jika CD/DVD ini diproduksi dan didistribusikan secara rutin kepada para petani. Selain itu, ponsel juga memiliki potensi untuk memberikan informasi terkini mengenai harga komoditas pertanian.

Kesimpulannya, hampir semua petani yang ditemui pada saat survei ini cenderung mengharapkan adanya perbaikan dalam layanan penyuluhan yang sudah didapatkan sekarang. Oleh karena itu, melalui proyek AgFor, layanan penyuluhan pertanian berpotensi dapat diperbaiki melalui a) pengenalan pada pengetahuan atau teknologi terbaru yang bisa memperbaiki produktivitas tanaman, dan b) bantuan praktis atau teknis yang rutin untuk meningkatkan mata pencaharian mereka. 


\section{Daftar Pustaka}

[BPS] Biro Pusat Statistik Bantaeng district. 2010. Bantaeng in Figures 2010. BPS Statistics. Bantaeng district, South Sulawesi: Biro Pusat Statistik Bantaeng district.

[BPS] Biro Pusat Statistik Bulukumba district. 2010. Bulukumba in Figures 2010. BPS Statistics. Bulukumba district: South Sulawesi province: Biro Pusat Statistik Bulukumba district.

[BPS] Biro Pusat Statistik Kolaka district. 2010. Kolaka in Figures 2010. BPS Statistics. Kolaka district, South East Sulawesi province: Biro Pusat Statistik Kolaka district.

[BPS] Biro Pusat Statistik Konawe district. 2008. Konawe in Figures 2008. BPS Statistics. Konawe district, South East Sulawesi province: Biro Pusat Statistik Konawe district.

[BPS] Biro Pusat Statistik South East Sulawesi province. 2011. South East Sulawesi in Figures 2011. BPS Statistics. South East Sulawesi province: Biro Pusat Statistik South East Sulawesi province.

Martini E, Tarigan J, Roshetko JM, Manurung G, Kurniawan I, Tukan J, Budidarsono S, Abdo M, and van Noordwijk M. 2008. Capacity Building Activities to Strengthen Agroforestry for Economic Development and Conservation. Working Paper No. 61. Bogor, Indonesia: World Agroforestry Centre - ICRAF, SEA Regional Office. P 70.

Roshetko JM, Nugraha E, Tukan JCM, Manurung G, Fay C, and van Noordwijk M. 2007a. Agroforestry for Livelihood Enhancement and Enterprise Development. In: Djoeroemana S, Myers B, Russell-Smith J, Blyth M, and Salean IET, eds. Integrated Rural Development in East Nusa Tenggara, Indonesia. Proceedings of a workshop to identify sustainable rural livelihoods, held in Kupang, Indonesia, 5-7 April 2006. ACIAR Proceedings 126, Australian Centre for International Agricultural Research. p 137-148.

Roshetko JM, Martini E, Tarigan J, Manurung G, Budidarsono S, Wijaya K, Tukan JC, Kurniawan I, Galudra G, Nugroho DK, Ekadinata A, Dewi S, Harja D, Lusiana B, van Noordwijk M, and Purba J. 2007b. Agroforestry on the Interface of Orangutan Conservation and Sustainable Livelihoods in Batang Toru (North Sumatra). Working Paper 56. Bogor, Indonesia: World Agroforestry Centre ICRAF, SEA Regional Office. P 26.

Roshetko JM, Suyanto, Dewi S, Sunderland T, Purwanto E, Perdana A, Millang S, Yuliani L, Purnomosidhi P, Tarigan J, Martini E, Finlayson R, Dahlia L. 2012. Agroforestry and forestry in Sulawesi: linking knowledge to action. First Annual Progress Report (April 2011-March 2012). Bogor, Indonesia: World Agroforestry Centre (ICRAF) Southeast Asia Regional Program; Center for International Forestry Research; Operation Wallacea Trust; Makassar, Indonesia: Faculty of Forestry, Hasanuddin University. P 102. 


\section{Lampiran}

Lampiran 1. Distribusi bibit yang sudah diberikan melalui program pemerintah kepada para petani di desa proyek AgFor Sulawesi Selatan (penerima adalah anggota kelompok petani)

\begin{tabular}{|c|c|c|c|c|}
\hline Desa & Tahun & $\begin{array}{l}\text { Frekuensi } \\
\text { per tahun }\end{array}$ & $\begin{array}{l}\text { Dinas } \\
\text { pemerintahan }\end{array}$ & Tanaman \\
\hline \multicolumn{5}{|c|}{ Kelompok desa berlahan terdegradasi } \\
\hline Kayu Loe & 2011 & 23 & $\begin{array}{l}\text { Dinas Pertanian; } \\
\text { Dinas Kehutanan }\end{array}$ & $\begin{array}{l}\text { Jagung, kentang; KBR-cengkeh, } \\
\text { kopi, durian }\end{array}$ \\
\hline Bonto Karaeng & 2011 & 1 & Dinas Pertanian & $\begin{array}{l}\text { Jagung (1520 kg per } \mathrm{HH}) \text {; cengkeh, } \\
50 \text { bibit per } \mathrm{HH} \text {; kakao, } 50 \text { bibit per } \\
\mathrm{HH} \text {; pafi ( } 1520 \text { kg per } \mathrm{HH})\end{array}$ \\
\hline \multicolumn{5}{|c|}{ Kelompok desa AF-Bantaeng } \\
\hline Campaga & $\begin{array}{l}2007 \\
\text { hingga } \\
2008\end{array}$ & 1 & $\begin{array}{l}\text { Dinas Pertanian; } \\
\text { Dinas } \\
\text { Perkebunan }\end{array}$ & Padi, jagung, kakao \\
\hline Pattaneteang & 2011 & 12 & $\begin{array}{l}\text { Dinas Kehutanan } \\
\text { dan Perkebunan }\end{array}$ & Cengkeh, duku, suren, durian \\
\hline \multicolumn{5}{|c|}{ Kelompok desa AF-Bulukumba } \\
\hline $\begin{array}{l}\text { Borong } \\
\text { Rappoa }\end{array}$ & $\begin{array}{l}2007 \\
2012\end{array}$ & $\begin{array}{l}1 \text { per } 5 \\
\text { tahun }\end{array}$ & $\begin{array}{l}\text { P2BM, Dinas } \\
\text { Pertanian }\end{array}$ & $\begin{array}{l}\text { Padi, jagung, durian, bawang, mahoni, } \\
\text { pala, kayu Afrika, jati putih }\end{array}$ \\
\hline $\begin{array}{l}\text { Balang } \\
\text { Pesoang }\end{array}$ & $\begin{array}{l}2005- \\
2012\end{array}$ & 1 & Dinas Pertanian & $\begin{array}{l}\text { Manggis, suren, jati, lada, cengkeh, } \\
\text { durian, kopi, rambutan }\end{array}$ \\
\hline \multicolumn{5}{|c|}{ Kelompok desa berbasis kayu } \\
\hline Tana Toa & 2012 & 1 & & $\begin{array}{l}\text { Jagung, padi, surian, jati, kakao, kemiri, } \\
\text { karet, jati putih, mahoni, sengon } \\
\text { buto/enterolobium (colo) }\end{array}$ \\
\hline Tugondeng & 2011 & 1 & $\begin{array}{l}\text { Dinas Pertanian, } \\
\text { Dinas Kehutanan }\end{array}$ & $\begin{array}{l}\text { Padi, jagung, jati, kelapa, mahoni, jati } \\
\text { putih, kayu sengon }\end{array}$ \\
\hline
\end{tabular}

Catatan: $\mathrm{HH}=$ rumah tangga. 
Lampiran 2. Pelatihan-pelatihan pertanian yang sudah pernah dilakukan di desa proyek AgFor Sulawesi Selatan

\begin{tabular}{|c|c|c|c|c|c|}
\hline Desa & Tahun & $\begin{array}{l}\text { Frekuensi } \\
\text { per tahun }\end{array}$ & $\begin{array}{c}\text { Badan } \\
\text { penyuluhan }\end{array}$ & Topik & $\begin{array}{c}\text { Partisipasi } \\
\text { perempuan (\%) }\end{array}$ \\
\hline \multicolumn{6}{|c|}{ Kelompok desa berlahan terdegradasi } \\
\hline Kayu Loe & 2011 & 1 per 3 tahun & Dinas Pertanian & Budi daya sayuran & 20 \\
\hline $\begin{array}{l}\text { Bonto } \\
\text { Karaeng }\end{array}$ & 2011 & 1 & $\begin{array}{l}\text { Penyuluh tingkat } \\
\text { kabupaten }\end{array}$ & $\begin{array}{l}\text { Industri rumah tangga } \\
\text { (membuat kursi) }\end{array}$ & 20 \\
\hline \multicolumn{6}{|c|}{ Kelompok desa AF-Bantaeng } \\
\hline Campaga & 2010 & 2 & $\begin{array}{l}\text { Penyuluh tingkat } \\
\text { kabupaten }\end{array}$ & Produksi madu & 50 \\
\hline Pattaneteang & 2011 & 1 & $\begin{array}{l}\text { Dinas Pertanian; } \\
\text { Dinas Kehutanan }\end{array}$ & Pemupukan & 10 \\
\hline \multicolumn{6}{|c|}{ Kelompok desa AF-Bulukumba } \\
\hline $\begin{array}{l}\text { Borong } \\
\text { Rappoa }\end{array}$ & 2011 & & Dinas Pertanian & Budi daya sayuran & 20 \\
\hline $\begin{array}{l}\text { Balang } \\
\text { Pesoang }\end{array}$ & 2011 & 1 & Dinas Pertanian & Enten samping kakao & 0 \\
\hline \multicolumn{6}{|c|}{ Kelompok desa berbasis kayu } \\
\hline Tana Toa & 2011 & 1 & $\begin{array}{l}\text { Dinas Pariwisata, } \\
\text { Dinas Pertanian }\end{array}$ & $\begin{array}{l}\text { Industri rumah tangga, } \\
\text { pengelolaan pengaturan } \\
\text { jarak tanaman }\end{array}$ & 50 \\
\hline Tugondeng & 2010 & 1 & $\begin{array}{l}\text { Dinas Pertanian, } \\
\text { Dinas Kehutanan }\end{array}$ & Budi daya kakao & 30 \\
\hline
\end{tabular}


Lampiran 3. Kegiatan penyuluhan pertanian di kelas yang sudah dilakukan sebagai bagian dari layanan penyuluhan pemerintah di desa proyek AgFor Sulawesi Selatan

\begin{tabular}{|c|c|c|c|c|c|}
\hline Desa & Tahun & $\begin{array}{l}\text { Frekuensi } \\
\text { per tahun }\end{array}$ & $\begin{array}{c}\text { Badan } \\
\text { penyuluhan }\end{array}$ & Topik & $\begin{array}{c}\text { Partisipasi perempuan } \\
(\%)\end{array}$ \\
\hline \multicolumn{6}{|c|}{ Kelompok desa berlahan terdegradasi } \\
\hline Kayu Loe & Tidak ada & & & & \\
\hline $\begin{array}{l}\text { Bonto } \\
\text { Karaeng }\end{array}$ & 2011 & $\begin{array}{l}\text { Bonto } \\
\text { Karaeng }\end{array}$ & 2011 & Bonto Karaeng & 2011 \\
\hline \multicolumn{6}{|c|}{ Kelompok desa AF-Bantaeng } \\
\hline Campaga & 2011 & 2 & $\begin{array}{l}\text { Unhas, } \\
\text { Dinas } \\
\text { Pertanian, } \\
\text { Dinas } \\
\text { Perkebunan }\end{array}$ & $\begin{array}{l}\text { Budi daya tanaman } \\
\text { pangan pokok dan } \\
\text { tanaman } \\
\text { perkebunan; hutan } \\
\text { lindung; ekowisata }\end{array}$ & 30 \\
\hline Pattaneteang & $\begin{array}{l}200- \\
2010\end{array}$ & 1 & $\begin{array}{l}\text { Dinas } \\
\text { Pertanian; } \\
\text { Dinas } \\
\text { Kehutanan }\end{array}$ & Budi daya & 30 \\
\hline \multicolumn{6}{|c|}{ Kelompok desa AF-Bulukumba } \\
\hline $\begin{array}{l}\text { Borong } \\
\text { Rappoa }\end{array}$ & 2011 & 1 per 5 tahun & $\begin{array}{l}\text { Dinas } \\
\text { Pertanian }\end{array}$ & $\begin{array}{l}\text { Budi daya sayuran } \\
\text { dan padi }\end{array}$ & 30 \\
\hline $\begin{array}{l}\text { Balang } \\
\text { Pesoang }\end{array}$ & Tidak ada & & & & \\
\hline \multicolumn{6}{|c|}{ Kelompok desa berbasis kayu } \\
\hline Tana Toa & $\begin{array}{l}2011 \\
2012\end{array}$ & 4 per 3 tahun & $\begin{array}{l}\text { Lapesda- } \\
\text { UGM }\end{array}$ & $\begin{array}{l}\text { Industri pupuk } \\
\text { organik, industri } \\
\text { tekstil traditional }\end{array}$ & 80 \\
\hline Tugondeng & 2010 & 1 & $\begin{array}{l}\text { Dinas } \\
\text { Pertanian, } \\
\text { Dinas } \\
\text { Kehutanan }\end{array}$ & $\begin{array}{l}\text { Enten samping } \\
\text { kakao; produksi } \\
\text { gula kelapa }\end{array}$ & 30 \\
\hline
\end{tabular}


Lampiran 4. Daftar kegiatan kunjungan silang yang sudah dilakukan oleh badan pemerintahan dan nonpemerintah di Sulawesi Selatan

\begin{tabular}{|c|c|c|c|c|c|}
\hline Desa & Tahun & $\begin{array}{l}\text { Frekuensi } \\
\text { per tahun }\end{array}$ & Badan & Tujuan/agenda & $\begin{array}{c}\text { Partisipasi } \\
\text { perempuan (\%) }\end{array}$ \\
\hline \multicolumn{6}{|c|}{ Kelompok desa berlahan terdegradasi } \\
\hline Kayu Loe & 2011 & 2 & Dinas Pertanian dan Hortikultura & Bali dan Bulukumba & 30 \\
\hline Bonto Karaeng & 2011 & 1 & Dinas Pertanian & Pengelolaan unggas & $?$ \\
\hline \multicolumn{6}{|c|}{ Kelompok desa AF-Bantaeng } \\
\hline Campaga & 2010 & 1 & $\begin{array}{l}\text { Dinas Pertanian dan Hortikultura; } \\
\text { Kelompok Tani Nelayan Andalan }\end{array}$ & & 50 \\
\hline Pattaneteang & 2011 & 1 & $\begin{array}{l}\text { Dinas Kehutanan; Universitas } \\
\text { Hasanuddin }\end{array}$ & Produksi madu & 0 \\
\hline \multicolumn{6}{|c|}{ Kelompok desa AF-Bulukumba } \\
\hline Borong Rappoa & 2009 & $\begin{array}{c}1 \text { per } 10 \\
\text { tahun }\end{array}$ & Dinas Pertanian & $\begin{array}{l}\text { Enrekang dan Tana Toraja untuk mempelajari } \\
\text { budi daya sayuran ( } 27 \text { partisipan, } 4 \\
\text { perempuan) }\end{array}$ & 20 \\
\hline Balang Pesoang & Tidak ada & & & & \\
\hline \multicolumn{6}{|c|}{ Kelompok desa berbasis kayu } \\
\hline Tana Toa & $\begin{array}{l}1996,2003 \\
2006\end{array}$ & & & Pertemuan Komunitas Adat tingkat Nasional & 0 \\
\hline Tugondeng & 2010 & $\begin{array}{l}1 \text { per } 5 \\
\text { tahun }\end{array}$ & Dinas Kehutanan dan Perkebunan & Kakao di Banyuwangi, Jawa Timur & 0 \\
\hline
\end{tabular}


Annex 5. Cross-visits requested by South Sulawesi farmers in the AgFor project

\begin{tabular}{|c|c|c|c|c|c|c|c|c|c|c|c|c|c|}
\hline \multirow[b]{2}{*}{ Desa } & \multirow[b]{2}{*}{ Topik } & \multicolumn{12}{|c|}{ Lokasi untuk kunjungan silang } \\
\hline & & $\begin{array}{l}\text { Malino } \\
\text { (kopi, } \\
\text { sayuran, } \\
\text { buah) }\end{array}$ & $\begin{array}{l}\text { Bantaeng- } \\
\text { Loka } \\
\text { (sayuran, } \\
\text { apel, } \\
\text { stroberi) }\end{array}$ & $\begin{array}{l}\text { Enrekang } \\
\text { (sayuran, } \\
\text { sapi, salak) }\end{array}$ & $\begin{array}{l}\text { Sidrap } \\
\text { (padi, } \\
\text { unggas) }\end{array}$ & $\begin{array}{l}\text { Tator } \\
\text { (kopi) }\end{array}$ & $\begin{array}{c}\text { Takalar } \\
\text { (jagung } \\
\text { ) }\end{array}$ & $\begin{array}{c}\text { Sinjai Barat } \\
\text { (markisa) }\end{array}$ & $\begin{array}{l}\text { Palopo } \\
\text { (kakao, } \\
\text { sagu) }\end{array}$ & $\begin{array}{l}\text { Bulu- } \\
\text { kumba } \\
\text { (karet, } \\
\text { buah) }\end{array}$ & $\begin{array}{c}\text { Sinjai } \\
\text { (durian) }\end{array}$ & $\begin{array}{l}\text { Soppeng } \\
\text { (gaharu) }\end{array}$ & $\begin{array}{l}\text { Kendari } \\
\text { (cengkeh) }\end{array}$ \\
\hline \multicolumn{14}{|c|}{ Kelompok desa berlahan terdegradasi } \\
\hline Bonto Karaeng & $\begin{array}{l}\text { Sayuran; sapi; } \\
\text { unggas; buah }\end{array}$ & $v$ & & $\mathrm{~V}$ & $v$ & & & & & & & & \\
\hline \multicolumn{14}{|c|}{ Kelompok desa AF-Bantaeng } \\
\hline Campaga & $\begin{array}{l}\text { Padi;kakao;sapi; } \\
\text { salak; jagung; } \\
\text { markisa }\end{array}$ & & & $\mathrm{V}$ & $v$ & & V & $v$ & $v$ & & & & \\
\hline Pattaneteang & $\begin{array}{l}\text { Pala; manggis; padi; } \\
\text { sapi; kambing; } \\
\text { gaharu; cengkeh; } \\
\text { kakao }\end{array}$ & & & & & & & & $v$ & & & $v$ & $v$ \\
\hline
\end{tabular}




\begin{tabular}{|c|c|c|c|c|c|c|c|c|c|c|c|c|c|}
\hline \multirow[b]{2}{*}{ Desa } & \multirow[b]{2}{*}{ Topik } & \multicolumn{12}{|c|}{ Lokasi untuk kunjungan silang } \\
\hline & & $\begin{array}{l}\text { Malino } \\
\text { (kopi, } \\
\text { sayuran, } \\
\text { buah) }\end{array}$ & $\begin{array}{l}\text { Bantaeng- } \\
\text { Loka } \\
\text { (sayuran, } \\
\text { apel, } \\
\text { stroberi) }\end{array}$ & $\begin{array}{l}\text { Enrekang } \\
\text { (sayuran, } \\
\text { sapi, salak) }\end{array}$ & $\begin{array}{l}\text { Sidrap } \\
\text { (padi, } \\
\text { unggas) }\end{array}$ & $\begin{array}{l}\text { Tator } \\
\text { (kopi) }\end{array}$ & $\begin{array}{c}\text { Takalar } \\
\text { (jagung } \\
\text { ) }\end{array}$ & $\begin{array}{c}\text { Sinjai Barat } \\
\text { (markisa) }\end{array}$ & $\begin{array}{c}\text { Palopo } \\
\text { (kakao, } \\
\text { sagu) }\end{array}$ & $\begin{array}{c}\text { Bulu- } \\
\text { kumba } \\
\text { (karet, } \\
\text { buah) }\end{array}$ & $\begin{array}{l}\text { Sinjai } \\
\text { (durian) }\end{array}$ & $\begin{array}{l}\text { Soppeng } \\
\text { (gaharu) }\end{array}$ & $\begin{array}{c}\text { Kendari } \\
\text { (cengkeh) }\end{array}$ \\
\hline \multicolumn{14}{|c|}{ Kelompok desa AF-Bulukumba } \\
\hline $\begin{array}{l}\text { Borong } \\
\text { Rappoa }\end{array}$ & $\begin{array}{l}\text { Kopi; sayuran; } \\
\text { unggas; cengkeh }\end{array}$ & $v$ & $v$ & V & $v$ & $v$ & & & & & & & \\
\hline $\begin{array}{l}\text { Balang } \\
\text { Pesoang }\end{array}$ & $\begin{array}{l}\text { Rambutan, durian, } \\
\text { apel, stroberi }\end{array}$ & $v$ & $v$ & & & & & & & & & & \\
\hline \multicolumn{14}{|c|}{ Kelompok desa berbasis kayu } \\
\hline Tana Toa & Karet, durian & & & & & & & & & v & $\mathrm{v}$ & & \\
\hline Tugondeng & $\begin{array}{l}\text { Kakao, kelapa, } \\
\text { karet }\end{array}$ & & & & & & & & $v$ & & & & \\
\hline
\end{tabular}


Lampiran 6. Distribusi bibit yang sudah diberikan melalui program pemerintah kepada para petani di desa proyek AgFor Sulawesi Tenggara (penerima adalah anggota kelompok petani)

\begin{tabular}{|c|c|c|c|c|}
\hline Desa & Tahun & Frekuensi & $\begin{array}{c}\text { Badan } \\
\text { Pemerintahan }\end{array}$ & Tanaman \\
\hline \multicolumn{5}{|c|}{ Kelompok desa lokal } \\
\hline Ambondiaa & $\begin{array}{l}2009 \\
2010 \\
2011\end{array}$ & Not sure & $\begin{array}{l}\text { Dinas } \\
\text { Perkebunan;Dinas } \\
\text { Pertanian; Dinas } \\
\text { Kehutanan }\end{array}$ & Cacao, rambutan, paddy, teak \\
\hline Lamunde & $\begin{array}{l}2004 \\
2008\end{array}$ & Not sure & $\begin{array}{l}\text { Dinas Pertanian; } \\
\text { Dinas Perkebunan }\end{array}$ & $\begin{array}{l}\text { Paddy, durian, cacao, pepper, } \\
\text { patchouli, teak }\end{array}$ \\
\hline Simbune & 2009 & Not sure & $\begin{array}{l}\text { Gernas, Dinas } \\
\text { Perkebunan }\end{array}$ & $\begin{array}{l}\text { Cacao seedlings for budwood garden } \\
\text { with cacao variety of Sulawesi } 1 \text { and } \\
\text { Sulawesi } 2\end{array}$ \\
\hline Taosu & 1997 & Not sure & & $\begin{array}{l}\text { Teak, paraserianthes, oilpalm, } \\
\text { coconut hybrid }\end{array}$ \\
\hline \multicolumn{5}{|c|}{ Kelompok desa campuran } \\
\hline Anggawo & None & & & \\
\hline Lawonua & & $\begin{array}{l}1 \text { per } 10 \\
\text { years }\end{array}$ & $?$ & Cacao \\
\hline $\begin{array}{l}\text { Wonua Hoa- } \\
\text { local }\end{array}$ & $\begin{array}{l}2009- \\
2010\end{array}$ & Not sure & Dinas Pertanian & Paddy \\
\hline $\begin{array}{l}\text { Wonua Hoa- } \\
\text { migrant }\end{array}$ & 2011 & Not sure & Dinas Pertanian & Durian otong (100 seedlings) \\
\hline \multicolumn{5}{|c|}{ Kelompok desa transmigran } \\
\hline Tasahea & $\begin{array}{l}1994 \\
2011\end{array}$ & Not sure & $\begin{array}{l}\text { Dinas Perkebunan; } \\
\text { Dinas Kehutanan }\end{array}$ & $\begin{array}{l}\text { Cacao, gmelina, teak, mango, vitex, } \\
\text { rambutan aceh }\end{array}$ \\
\hline \multicolumn{5}{|c|}{ Kelompok desa transmigran baru } \\
\hline $\begin{array}{l}\text { UPT Asinua } \\
\text { Jaya (Lasao) }\end{array}$ & 2011 & Not sure & $\begin{array}{l}\text { Dinas Tenaga } \\
\text { Kerja dan } \\
\text { Transmigrasi }\end{array}$ & $\begin{array}{l}\text { Paddy, maize, soybeans, rambutan, } \\
\text { orange, mango, durian (all died, eaten } \\
\text { by pigs), cacao, vegetables, banana, } \\
\text { jackfruit }\end{array}$ \\
\hline
\end{tabular}


Lampiran 7. Pelatihan-pelatihan pertanian yang sudah pernah dilakukan di desa proyek AgFor Sulawesi Tenggara

\begin{tabular}{|c|c|c|c|c|c|}
\hline Desa & Tahun & Frekuensi & $\begin{array}{c}\text { Badan } \\
\text { penyuluhan }\end{array}$ & Topik & $\begin{array}{c}\text { Partisipasi } \\
\text { perempuan (\%) }\end{array}$ \\
\hline \multicolumn{6}{|c|}{ Kelompok desa lokal } \\
\hline Ambondiaa & $\begin{array}{l}2004 \\
2011\end{array}$ & Tidak yakin & Gernas, SL & $\begin{array}{l}\text { Rehabilitasi dan } \\
\text { perawatan kakao; enten } \\
\text { samping }\end{array}$ & 30 \\
\hline Lamunde & $\begin{array}{l}2009- \\
2010\end{array}$ & Tidak yakin & Gernas & $\begin{array}{l}\text { Enten samping kakao; } \\
\text { pembuatan kompos }\end{array}$ & 25 \\
\hline Simbune & 2009 & Tidak yakin & $\begin{array}{l}\text { Gernas, } \\
\text { Dinas } \\
\text { Perkebunan }\end{array}$ & $\begin{array}{l}\text { Enten samping kakao } \\
\text { ( } 20 \text { okulator, semua } \\
\text { jantan); pemangkasan } \\
\text { kakao; sekolah lapang } \\
\text { pertanian ( } 25 \text { partisipan, } \\
7 \text { partisipan per } \\
\text { kelompok petani) }\end{array}$ & 10 \\
\hline Taosu & $\begin{array}{l}2004 \\
2009\end{array}$ & Tidak yakin & $\begin{array}{l}\text { Dinas } \\
\text { Pertanian }\end{array}$ & Enten jeruk & 10 \\
\hline \multicolumn{6}{|c|}{ Kelompok desa campuran } \\
\hline Anggawo & 2011 & & $\begin{array}{l}\text { Dinas } \\
\text { Kehutanan }\end{array}$ & $\begin{array}{l}\text { Pembibitan untuk jenis } \\
\text { pohon kayu (KBR) }\end{array}$ & 30 \\
\hline Lawonua & $\begin{array}{l}2008- \\
2009\end{array}$ & 1 per 4 tahun & $?$ & Pembuatan kompos & 50 \\
\hline $\begin{array}{l}\text { Wonua } \\
\text { Hoa-local }\end{array}$ & $\begin{array}{l}2008- \\
2012\end{array}$ & 1 per 2 tahun & $\begin{array}{l}\text { Dinas } \\
\text { Perkebunan }\end{array}$ & Enten samping kakao & 15 \\
\hline $\begin{array}{l}\text { Wonua } \\
\text { Hoa- } \\
\text { migrant }\end{array}$ & None & & & & \\
\hline \multicolumn{6}{|c|}{ Kelompok desa transmigran } \\
\hline Tasahea & 2007 & Tidak yakin & $\begin{array}{l}\text { Gernas, } \\
\text { Dinas } \\
\text { Perkebunan, } \\
\text { Farmer Field } \\
\text { School (SL- } \\
\text { PAT) }\end{array}$ & $\begin{array}{l}\text { Enten samping kakao, } \\
\text { produksi pupuk organik, } \\
\text { pengelolaan biogas } \\
\text { untuk energi alternatif }\end{array}$ & 30 \\
\hline \multicolumn{6}{|c|}{ Kelompok desa transmigran baru } \\
\hline $\begin{array}{l}\text { UPT Asinua } \\
\text { Jaya } \\
\text { (Lasao) }\end{array}$ & $\begin{array}{l}2010- \\
2011\end{array}$ & Tidak yakin & $\begin{array}{l}\text { Dinas } \\
\text { Tenaga } \\
\text { Kerja dan } \\
\text { Transmigrasi } \\
\text { provinsi } \\
\text { Sulawesi } \\
\text { Tenggara }\end{array}$ & $\begin{array}{l}\text { Industri rumah tangga } \\
\text { (membuat makanan); } \\
\text { industri pupuk organik; } \\
\text { penanggulangan hama } \\
\text { dan penyakit }\end{array}$ & 30 \\
\hline
\end{tabular}


Lampiran 8. Kegiatan penyuluhan pertanian di kelas yang sudah dilakukan sebagai bagian dari layanan penyuluhan pemerintah di desa proyek AgFor Sulawesi Tenggara

\begin{tabular}{|c|c|c|c|c|c|}
\hline Desa & Tahun & Frekuensi & $\begin{array}{c}\text { Badan } \\
\text { penyuluhan }\end{array}$ & Topik & $\begin{array}{c}\text { Partisipasi } \\
\text { perempuan (\%) }\end{array}$ \\
\hline \multicolumn{6}{|c|}{ Kelompok desa lokal } \\
\hline Ambondiaa & $\begin{array}{l}2004 \\
2011\end{array}$ & $\begin{array}{l}\text { Tidak } \\
\text { yakin }\end{array}$ & $\begin{array}{l}\text { Gernas, Sekolah } \\
\text { Lapang }\end{array}$ & $\begin{array}{l}\text { Rehabilitasi, } \\
\text { perawatan, enten } \\
\text { samping kakao }\end{array}$ & 30 \\
\hline Lamunde & $\begin{array}{l}2009- \\
2010\end{array}$ & $\begin{array}{l}\text { Tidak } \\
\text { yakin }\end{array}$ & Dinas Pertanian & Sawah padi & 50 \\
\hline Simbune & $\begin{array}{l}2007 \\
2009 \\
2011\end{array}$ & $\begin{array}{l}\text { Tidak } \\
\text { yakin }\end{array}$ & $\begin{array}{l}\text { Gernas, Dinas } \\
\text { Perkebunan }\end{array}$ & $\begin{array}{l}\text { Enten samping } \\
\text { dan pemangkasan } \\
\text { kakao; sekolah } \\
\text { lapang petani }\end{array}$ & 10 \\
\hline Taosu & $\begin{array}{l}2008 \\
2011\end{array}$ & $\begin{array}{l}\text { Tidak } \\
\text { yakin }\end{array}$ & Gernas & Enten kakao & 10 \\
\hline \multicolumn{6}{|c|}{ Kelompok desa campuran } \\
\hline Anggawo & 2011 & $\begin{array}{l}\text { Tidak } \\
\text { yakin }\end{array}$ & $\begin{array}{l}\text { Dinas Pertanian; } \\
\text { Dinas Kehutanan }\end{array}$ & $\begin{array}{l}\text { Penanggulangan } \\
\text { hama dan } \\
\text { penyakit terpadu; } \\
\text { pembibitan untuk } \\
\text { jenis pohon kayu } \\
\text { (KBR) }\end{array}$ & 30 \\
\hline Lawonua & $\begin{array}{l}2009- \\
2011\end{array}$ & $\begin{array}{l}1 \text { per } \\
\text { tahun }\end{array}$ & $?$ & Enten samping & 20 \\
\hline $\begin{array}{l}\text { Wonua } \\
\text { Hoa-local }\end{array}$ & 1998 & $\begin{array}{l}2 \text { per } \\
\text { tahun }\end{array}$ & $\begin{array}{l}\text { Dinas Pertanian } \\
\text { Kendari }\end{array}$ & Budi daya padi & 15 \\
\hline $\begin{array}{l}\text { Wonua } \\
\text { Hoa- } \\
\text { migrant }\end{array}$ & $\begin{array}{l}\text { Tidak } \\
\text { ada }\end{array}$ & & & & \\
\hline \multicolumn{6}{|c|}{ Kelompok desa transmigran } \\
\hline Tasahea & 2011 & $\begin{array}{l}\text { Tidak } \\
\text { yakin }\end{array}$ & $\begin{array}{l}\text { Dinas } \\
\text { Peternakan }\end{array}$ & $\begin{array}{l}\text { Pengelolaan } \\
\text { ternak sapi }\end{array}$ & 40 \\
\hline \multicolumn{6}{|c|}{ Kelompok desa transmigran baru } \\
\hline $\begin{array}{l}\text { UPT Asinua } \\
\text { Jaya } \\
\text { (Lasao) }\end{array}$ & $\begin{array}{l}2009 \\
2011\end{array}$ & $\begin{array}{l}\text { Tidak } \\
\text { yakin }\end{array}$ & $\begin{array}{l}\text { TKPMP, } \\
\text { DepNaKerTrans, } \\
\text { Balai } \\
\text { Transmigrasi } \\
\text { Makassar }\end{array}$ & $\begin{array}{l}\text { Budi daya kakao } \\
\text { dan sayuran }\end{array}$ & 30 \\
\hline
\end{tabular}


Lampiran 9. Daftar kegiatan kunjungan silang yang sudah dilakukan oleh badan pemerintahan dan nonpemerintah di Sulawesi Tenggara

\begin{tabular}{|c|c|c|c|c|c|}
\hline Desa & Tahun & Frekuensi & Badan & Tujuan/agenda & $\begin{array}{c}\text { Partisipasi } \\
\text { perempuan (\%) }\end{array}$ \\
\hline \multicolumn{6}{|l|}{ Kelompok desa lokal } \\
\hline Ambondiaa & Tidak ada & & & & \\
\hline Lamunde & 2008 & Tidak yakin & BUMDES & Tata kelola desa & 0 \\
\hline Simbune & 2004 & Tidak yakin & $\begin{array}{l}\text { Program } \\
\text { desentralisasi }\end{array}$ & Di Sinjai mempelajari budi daya vanilla & 30 \\
\hline Taosu & Tidak ada & & & Sosialisasi HKm di Bogor & \\
\hline \multicolumn{6}{|c|}{ Kelompok desa campuran } \\
\hline Anggawo & 2011 & & Gernas & Di Kolaka mempelajari budi daya kakao & 0 \\
\hline Lawonua & 2011 & Tidak yakin & Tidak yakin & Di Ladongi mempelajari budi daya kakao & 10 \\
\hline Wonua Hoa-local & Tidak ada & & & & \\
\hline Wonua Hoa-migrant & Tidak ada & & & & \\
\hline \multicolumn{6}{|c|}{ Kelompok desa transmigran } \\
\hline Tasahea & 2011 & Tidak yakin & Dinas Peternakan & Di Ladono, Konawe Selatan, mempelajari pengelolaan ternak sapi & 0 \\
\hline \multicolumn{6}{|c|}{ Kelompok desa transmigran baru } \\
\hline $\begin{array}{l}\text { UPT Asinua Jaya } \\
\text { (Lasao) }\end{array}$ & Tidak ada & & & & \\
\hline
\end{tabular}


Lampiran 10. Kunjungan silang yang diminta oleh para petani Sulawesi Tenggara melalui proyek AgFor

\begin{tabular}{|c|c|c|c|c|c|c|c|c|}
\hline \multirow[b]{2}{*}{ Desa } & \multirow[b]{2}{*}{ Topik } & \multicolumn{7}{|c|}{ Lokasi untuk kunjungan silang } \\
\hline & & $\begin{array}{c}\text { Bulukumba } \\
\text { (cengkeh, } \\
\text { karet, durian) }\end{array}$ & $\begin{array}{c}\text { Ladongi } \\
\text { (kelompok } \\
\text { pemasaran) }\end{array}$ & $\begin{array}{c}\text { Sinjai } \\
\text { (durian) }\end{array}$ & $\begin{array}{l}\text { Palopo } \\
\text { (durian) }\end{array}$ & $\begin{array}{c}? ? \\
\text { (lada) }\end{array}$ & $\begin{array}{c}\text { Lambandia } \\
\text { (kakao) }\end{array}$ & $\begin{array}{l}\text { Maros } \\
\text { (padi) }\end{array}$ \\
\hline \multicolumn{9}{|c|}{ Kelompok desa lokal } \\
\hline Ambondiaa & Kakao, karet & $\mathrm{v}$ & & & & & $v$ & \\
\hline Lamunde & Karet, cengkeh, kakao, lada & $\mathrm{v}$ & & & v & $\mathrm{v}$ & $\mathrm{v}$ & \\
\hline Simbune & $\begin{array}{l}\text { Kakao and kelompok pemasaran } \\
\text { (Lembaga Ekonomi Masyarakat) }\end{array}$ & & $\mathrm{v}$ & & & & & \\
\hline Taosu & Kakao & & & & & & $\mathrm{v}$ & \\
\hline \multicolumn{9}{|c|}{ Kelompok desa campuran } \\
\hline Anggawo & Kakao, durian & & & $\mathrm{v}$ & $\mathrm{v}$ & & $\mathrm{v}$ & \\
\hline Lawonua & Karet & v & & v & & & & \\
\hline $\begin{array}{l}\text { Wonua Hoa- } \\
\text { migrant }\end{array}$ & Cengkeh, durian, karet, kakao & $v$ & & $v$ & $v$ & & $v$ & \\
\hline Wonua Hoa-local & Padi, perikanan, kakao & & & & & & $\mathrm{v}$ & v \\
\hline \multicolumn{9}{|c|}{ Kelompok desa transmigran } \\
\hline Tasahea & Kakao, lada, durian & $v$ & $v$ & $v$ & $v$ & $v$ & $v$ & \\
\hline \multicolumn{9}{|c|}{ Kelompok desa transmigran baru } \\
\hline $\begin{array}{l}\text { UPT Asinua Jaya } \\
\text { (Lasao) }\end{array}$ & $\begin{array}{l}\text { Karet, cengkeh, durian, jati, } \\
\text { kelapa }\end{array}$ & v & & v & v & & v & \\
\hline
\end{tabular}




\section{WORKING PAPERS IN THIS SERIES}

\section{5}

1. Agroforestry in the drylands of eastern Africa: a call to action

2. Biodiversity conservation through agroforestry: managing tree species diversity within a network of community-based, nongovernmental, governmental and research organizations in western Kenya.

3. Invasion of prosopis juliflora and local livelihoods: Case study from the Lake Baringo area of Kenya

4. Leadership for change in farmers organizations: Training report: Ridar Hotel, Kampala, 29th March to 2nd April 2005.

5. Domestication des espèces agroforestières au Sahel : situation actuelle et perspectives

6. Relevé des données de biodiversité ligneuse: Manuel du projet biodiversité des parcs agroforestiers au Sahel

7. Improved land management in the Lake Victoria Basin: TransVic Project's draft report.

8. Livelihood capital, strategies and outcomes in the Taita hills of Kenya

9. Les espèces ligneuses et leurs usages: Les préférences des paysans dans le Cercle de Ségou, au Mali

10. La biodiversité des espèces ligneuses: Diversité arborée et unités de gestion du terroir dans le Cercle de Ségou, au Mali

\section{6}

11. Bird diversity and land use on the slopes of Mt. Kilimanjaro and the adjacent plains, Tanzania

12. Water, women and local social organization in the Western Kenya Highlands

13. Highlights of ongoing research of the World Agroforestry Centre in Indonesia

14. Prospects of adoption of tree-based systems in a rural landscape and its likely impacts on carbon stocks and farmers' welfare: The FALLOW Model Application in Muara Sungkai, Lampung, Sumatra, in a 'Clean Development Mechanism' context

15. Equipping integrated natural resource managers for healthy Agroforestry landscapes.

17. Agro-biodiversity and CGIAR tree and forest science: approaches and examples from Sumatra.

18. Improving land management in eastern and southern Africa: A review of policies.

19. Farm and household economic study of Kecamatan Nanggung, Kabupaten Bogor, Indonesia: A socio-economic base line study of Agroforestry innovations and livelihood enhancement.

20. Lessons from eastern Africa's unsustainable charcoal business.

21. Evolution of RELMA's approaches to land management: Lessons from two decades of research and development in eastern and southern Africa

22. Participatory watershed management: Lessons from RELMA's work with farmers in eastern Africa.

23. Strengthening farmers' organizations: The experience of RELMA and ULAMP.

24. Promoting rainwater harvesting in eastern and southern Africa.

25. The role of livestock in integrated land management.

26. Status of carbon sequestration projects in Africa: Potential benefits and challenges to scaling up.

27. Social and Environmental Trade-Offs in Tree Species Selection: A Methodology for Identifying Niche Incompatibilities in Agroforestry [Appears as AHI Working Paper no. 9]

28. Managing tradeoffs in agroforestry: From conflict to collaboration in natural resource management. [Appears as AHI Working Paper no. 10]

29. Essai d'analyse de la prise en compte des systemes agroforestiers pa les legislations forestieres au Sahel: Cas du Burkina Faso, du Mali, du Niger et du Senegal.

30. Etat de la recherche agroforestière au Rwanda etude bibliographique, période 1987-2003 


\section{7}

31. Science and technological innovations for improving soil fertility and management in Africa: A report for NEPAD's Science and Technology Forum.

32. Compensation and rewards for environmental services.

33. Latin American regional workshop report compensation.

34. Asia regional workshop on compensation ecosystem services.

35. Report of African regional workshop on compensation ecosystem services.

36. Exploring the inter-linkages among and between compensation and rewards for ecosystem services CRES and human well-being

37. Criteria and indicators for environmental service compensation and reward mechanisms: realistic, voluntary, conditional and pro-poor

38. The conditions for effective mechanisms of compensation and rewards for environmental services.

39. Organization and governance for fostering Pro-Poor Compensation for Environmental Services.

40. How important are different types of compensation and reward mechanisms shaping poverty and ecosystem services across Africa, Asia \& Latin America over the Next two decades?

41. Risk mitigation in contract farming: The case of poultry, cotton, woodfuel and cereals in East Africa.

42. The RELMA savings and credit experiences: Sowing the seed of sustainability

43. Yatich J., Policy and institutional context for NRM in Kenya: Challenges and opportunities for Landcare.

44. Nina-Nina Adoung Nasional di So! Field test of rapid land tenure assessment (RATA) in the Batang Toru Watershed, North Sumatera.

45. Is Hutan Tanaman Rakyat a new paradigm in community based tree planting in Indonesia?

46. Socio-Economic aspects of brackish water aquaculture (Tambak) production in Nanggroe Aceh Darrusalam.

47. Farmer livelihoods in the humid forest and moist savannah zones of Cameroon.

48. Domestication, genre et vulnérabilité : Participation des femmes, des Jeunes et des catégories les plus pauvres à la domestication des arbres agroforestiers au Cameroun.

49. Land tenure and management in the districts around Mt Elgon: An assessment presented to the Mt Elgon ecosystem conservation programme.

50. The production and marketing of leaf meal from fodder shrubs in Tanga, Tanzania: A pro-poor enterprise for improving livestock productivity.

51. Buyers Perspective on Environmental Services (ES) and Commoditization as an approach to liberate ES markets in the Philippines.

52. Towards Towards community-driven conservation in southwest China: Reconciling state and local perceptions.

53. Biofuels in China: An Analysis of the Opportunities and Challenges of Jatropha curcas in Southwest China.

54. Jatropha curcas biodiesel production in Kenya: Economics and potential value chain development for smallholder farmers

55. Livelihoods and Forest Resources in Aceh and Nias for a Sustainable Forest Resource Management and Economic Progress

56. Agroforestry on the interface of Orangutan Conservation and Sustainable Livelihoods in Batang Toru, North Sumatra. 
58. Assessing the Hydrological Situation of Talau Watershed, Belu Regency, East Nusa Tenggara.

59. Kajian Kondisi Hidrologis DAS Talau, Kabupaten Belu, Nusa Tenggara Timur.

60. Kajian Kondisi Hidrologis DAS Kapuas Hulu, Kabupaten Kapuas Hulu, Kalimantan Barat.

61. Lessons learned from community capacity building activities to support agroforest as sustainable economic alternatives in Batang Toru orang utan habitat conservation program (Martini, Endri et al.)

62. Mainstreaming Climate Change in the Philippines.

63. A Conjoint Analysis of Farmer Preferences for Community Forestry Contracts in the Sumber Jaya Watershed, Indonesia.

64. The highlands: a shared water tower in a changing climate and changing Asia

65. Eco-Certification: Can It Deliver Conservation and Development in the Tropics.

66. Designing ecological and biodiversity sampling strategies. Towards mainstreaming climate change in grassland management.

67. Towards mainstreaming climate change in grassland management policies and practices on the Tibetan Plateau

68. An Assessment of the Potential for Carbon Finance in Rangelands

69 ECA Trade-offs Among Ecosystem Services in the Lake Victoria Basin.

69. The last remnants of mega biodiversity in West Java and Banten: an in-depth exploration of RaTA (Rapid Land Tenure Assessment) in Mount Halimun-Salak National Park Indonesia

70. Le business plan d'une petite entreprise rurale de production et de commercialisation des plants des arbres locaux. Cas de quatre pépinières rurales au Cameroun.

71. Les unités de transformation des produits forestiers non ligneux alimentaires au Cameroun. Diagnostic technique et stratégie de développement Honoré Tabuna et Ingratia Kayitavu.

72. Les exportateurs camerounais de safou (Dacryodes edulis) sur le marché sous régional et international. Profil, fonctionnement et stratégies de développement.

73. Impact of the Southeast Asian Network for Agroforestry Education (SEANAFE) on agroforestry education capacity.

74. Setting landscape conservation targets and promoting them through compatible land use in the Philippines.

75. Review of methods for researching multistrata systems.

76. Study on economic viability of Jatropha curcas L. plantations in Northern Tanzania assessing farmers' prospects via cost-benefit analysis

77. Cooperation in Agroforestry between Ministry of Forestry of Indonesia and International Center for Research in Agroforestry

78. "China's bioenergy future. an analysis through the Lens if Yunnan Province

79. Land tenure and agricultural productivity in Africa: A comparative analysis of the economics literature and recent policy strategies and reforms

80. Boundary organizations, objects and agents: linking knowledge with action in agroforestry watersheds

81. Reducing emissions from deforestation and forest degradation (REDD) in Indonesia: options and challenges for fair and efficient payment distribution mechanisms

82. Mainstreaming climate change into agricultural education: challenges and perspectives

83. Challenging conventional mindsets and disconnects in conservation: the emerging role of ecoagriculture in Kenya's landscape mosaics

84. Lesson learned RATA garut dan bengkunat: suatu upaya membedah kebijakan pelepasan kawasan hutan dan redistribusi tanah bekas kawasan hutan

85. The emergence of forest land redistribution in Indonesia

86. Commercial opportunities for fruit in Malawi

87. Status of fruit production processing and marketing in Malawi 
88. Fraud in tree science

89. Trees on farm: analysis of global extent and geographical patterns of agroforestry

90. The springs of Nyando: water, social organization and livelihoods in Western Kenya

91. Building capacity toward region-wide curriculum and teaching materials development in agroforestry education in Southeast Asia

92. Overview of biomass energy technology in rural Yunnan (Chinese - English abstract)

93. A pro-growth pathway for reducing net GHG emissions in China

94. Analysis of local livelihoods from past to present in the central Kalimantan Ex-Mega Rice Project area

95. Constraints and options to enhancing production of high quality feeds in dairy production in Kenya, Uganda and Rwanda

\section{0}

96. Agroforestry education in the Philippines: status report from the Southeast Asian Network for Agroforestry Education (SEANAFE)

97. Economic viability of Jatropha curcas L. plantations in Northern Tanzania- assessing farmers' prospects via cost-benefit analysis.

98. Hot spot of emission and confusion: land tenure insecurity, contested policies and competing claims in the central Kalimantan Ex-Mega Rice Project area

99. Agroforestry competences and human resources needs in the Philippines

100. CES/COS/CIS paradigms for compensation and rewards to enhance environmental Services

101. Case study approach to region-wide curriculum and teaching materials development in agroforestry education in Southeast Asia

102. Stewardship agreement to reduce emissions from deforestation and degradation (REDD): Lubuk Beringin's Hutan Desa as the first village forest in Indonesia

103. Landscape dynamics over time and space from ecological perspective

104. Komoditisasi atau koinvestasi jasa lingkungan: skema imbal jasa lingkungan program peduli sungai di DAS Way Besai, Lampung, Indonesia

105. Improving smallholders' rubber quality in Lubuk Beringin, Bungo district, Jambi province, Indonesia: an initial analysis of the financial and social benefits

106. Rapid Carbon Stock Appraisal (RACSA) in Kalahan, Nueva Vizcaya, Philippines

107. Tree domestication by ICRAF and partners in the Peruvian Amazon: lessons learned and future prospects in the domain of the Amazon Initiative eco-regional program

108. Memorias del Taller Nacional: "Iniciativas para Reducir la Deforestación en la region Andino Amazónica", 09 de Abril del 2010. Proyecto REALU Peru

109. Percepciones sobre la Equidad y Eficiencia en la cadena de valor de REDD en Perú -Reporte de Talleres en Ucayali, San Martín y Loreto, 2009. Proyecto REALU-Perú.

110. Reducción de emisiones de todos los Usos del Suelo. Reporte del Proyecto REALU Perú Fase 1

111. Programa Alternativas a la Tumba-y-Quema (ASB) en el Perú. Informe Resumen y Síntesis de la Fase II. 2da. versión revisada

112. Estudio de las cadenas de abastecimiento de germoplasma forestal en la amazonía Boliviana

113. Biodiesel in the Amazon

114. Estudio de mercado de semillas forestales en la amazonía Colombiana

115. Estudio de las cadenas de abastecimiento de germoplasma forestal en Ecuador

116. How can systems thinking, social capital and social network analysis help programs achieve impact at scale?

117. Energy policies, forests and local communities in the Ucayali Region, Peruvian Amazon

118. NTFPs as a Source of Livelihood Diversification for Local Communities in the Batang Toru Orangutan Conservation Program

119. Studi Biodiversitas: Apakah agroforestry mampu mengkonservasi keanekaragaman hayati di DAS Konto? 
120. Estimasi Karbon Tersimpan di Lahan-lahan Pertanian di DAS Konto, Jawa Timur

121. Implementasi Kaji Cepat Hidrologi (RHA) di Hulu DAS Brantas, Jawa Timur.

122. Kaji Cepat Hidrologi di Daerah Aliran Sungai Krueng Peusangan, NAD,Sumatra

123. A Study of Rapid Hydrological Appraisal in the Krueng Peusangan Watershed, NAD, Sumatra.

\section{1}

124. An Assessment of farm timber value chains in Mt Kenya area, Kenya

125. A Comparative financial analysis of current land use systems and implications for the adoption of improved agroforestry in the East Usambaras, Tanzania

126. Agricultural monitoring and evaluation systems

127. Challenges and opportunities for collaborative landscape governance in the East Usambara Mountains, Tanzania

128. Transforming Knowledge to Enhance Integrated Natural Resource Management Research, Development and Advocacy in the Highlands of Eastern Africa

129. Carbon-forestry projects in the Philippines: potential and challenges The Mt Kitanglad Range forest-carbon development

130. Carbon forestry projects in the Philippines: potential and challenges. The Arakan Forest Corridor forest-carbon project

131. Carbon-forestry projects in the Philippines: potential and challenges. The Laguna Lake Development Authority's forest-carbon development project

132. Carbon-forestry projects in the Philippines: potential and challenges. The Quirino forest-carbon development project in Sierra Madre Biodiversity Corridor

133. Carbon-forestry projects in the Philippines: potential and challenges. The Ikalahan ancestral domain forest-carbon development

134. The Importance of Local Traditional Institutions in the Management of Natural Resources in the Highlands of Eastern Africa

135. Socio-economic assessment of irrigation pilot projects in Rwanda

136. Performance of three rambutan varieties (Nephelium lappaceum L.) on various nursery media

137. Climate change adaptation and social protection in agroforestry systems: enhancing adaptive capacity and minimizing risk of drought in Zambia and Honduras

138. Does value chain development contribute to rural poverty reduction? Evidence of asset building by smallholder coffee producers in Nicaragua

139. Potential for biofuel feedstock in Kenya

140. Impact of fertilizer trees on maize production and food security in six districts of Malawi.

\section{2}

141. Fortalecimiento de capacidades para la gestión del Santuario Nacional Pampa Hermosa:

Construyendo las bases para un manejo adaptativo para el desarrollo local. Memorias del Proyect

142. Understanding rural institutional strengthening: A cross-level policy and institutional framework for sustainable development in Kenya

143. Climate change vulnerability of agroforestry

144. Rapid assesment of the inner Niger delta of Mali

145. Designing an incentive program to reduce on-farm deforestationin the East Usambara Mountains, Tanzania

146. Extent of adoption of conservation agriculture and agroforestry in Africa: the case of Tanzania, Kenya, Ghana, and Zambia 
147. Policy incentives for scaling up conservation agriculture with trees in Africa: the case of Tanzania, Kenya, Ghana and Zambia

148. Commoditized or co-invested environmental services? Rewards for environmental services scheme: River Care program Way Besai watershed, Lampung, Indonesia.

149. Assessment of the headwaters of the Blue Nile in Ethiopia.

150. Assessment of the uThukela Watershed, Kwazaulu.

151. Assessment of the Oum Zessar Watershed of Tunisia.

152. Assessment of the Ruwenzori Mountains in Uganda.

153. History of agroforestry research and development in Viet Nam. Analysis of research opportunities and gaps.

154. REDD+ in Indonesia: a Historical Perspective

155. Agroforestry and Forestry in Sulawesi series: Livelihood strategies and land use system dynamics in South Sulawesi

156. Agroforestry and Forestry in Sulawesi series: Livelihood strategies and land use system dynamics in Southeast Sulawesi.

157. Agroforestry and Forestry in Sulawesi series: Profitability and land-use systems in South and Southeast Sulawesi.

158. Agroforestry and Forestry in Sulawesi series: Gender, livelihoods and land in South and Southeast Sulawesi

159. Agroforestry and Forestry in Sulawesi series: Agroforestry extension needs at the community level in AgFor project sites in South and Southeast Sulawesi, Indonesia.

160. Agroforestry and Forestry in Sulawesi series: Rapid market appraisal of agricultural, plantation and forestry commodities in South and Southeast Sulawesi.

\section{3}

161. Diagnosis of farming systems in the Agroforestry for Livelihoods of Smallholder farmers in Northwestern Viet Nam project

162. Ecosystem vulnerability to climate change: a literature review

163. Local capacity for implementing payments for environmental services schemes: lessons from the RUPES project in northeastern Viet Nam

164. Seri Agroforestri dan Kehutanan di Sulawesi: Agroforestry dan Kehutanan di Sulawesi: Strategi mata pencaharian dan dinamika sistem penggunaan lahan di Sulawesi Selatan

165. Seri Agroforestri dan Kehutanan di Sulawesi: Mata pencaharian dan dinamika sistem penggunaan lahan di Sulawesi Tenggara

166. Seri Agroforestri dan Kehutanan di Sulawesi: Profitabilitas sistem penggunaan lahan di Sulawesi Selatan dan Sulawesi Tenggara

167. Seri Agroforestri dan Kehutanan di Sulawesi: Gender, mata pencarian dan lahan di Sulawesi Selatan dan Sulawesi Tenggara 

The World Agroforestry Centre is an autonomous, non-profit research organization whose vision is a rural transformation in the developing world as smallholder households increase their use of trees in agricultural landscapes to improve food security, nutrition, income, health, shelter, social cohesion, energy resources and environmental sustainability. The Centre generates science-based knowledge about the diverse roles that trees play in agricultural landscapes, and uses its research to advance policies and practices, and their implementation that benefit the poor and the environment. It aims to ensure that all this is achieved by enhancing the quality of its science work, increasing operational efficiency, building and maintaining strong partnerships, accelerating the use and impact of its research, and promoting greater cohesion, interdependence and alignment within the organization.

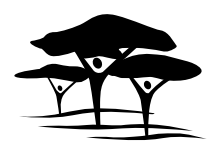

United Nations Avenue, Gigiri • PO Box 30677 • Nairobi, $00100 \cdot$ Kenya Telephone: +254207224000 or via USA +16508336645

Fax: +254207224001 or via USA +1 6508336646

Email: worldagroforestry@cgiar.org•www.worldagroforestry.org

Southeast Asia Regional Program • Sindang Barang • Bogor 16680

PO Box $161 \cdot$ Bogor $16001 \cdot$ Indonesia

Telephone: +62 $2518625415 \cdot$ Fax: +62 2518625416

Email: icraf-indonesia@cgiar.org•www.worldagroforestry.org/regions/southeast_asia 